\title{
Radiobiological Characterization Environment Around Object "Shelter"
}

\author{
Rashydov Namik et al.* \\ Institute Cell Biology E Genetic Engineering of NAS of Ukraine \\ Institute for Safety Problems of Nuclear Power Plants NAS of Ukraine \\ National University "Kyievo-Mogiljanskaja Academy" \\ Ukraine
}

\section{Introduction}

The quarter century away pass after Chornobyl catastrophe. As result there surrounding lands object "Shelter" remain heavily contaminated by long-living radioactivity isotopes for many years to come. Nuclear danger dividing materials of object "Shelter" represent open sources of ionizing radiation (IR) and define not potential only, but direct danger to the personnel and environment. Today in object "Shelter" is about $95 \%$ of highly active fuel loading of a reactor (an order 180 - $190 \mathrm{~T}$ of uranium and over $400 \mathrm{~kg}$ of plutonium). These danger materials are in different updating - in the form of active zone fragments, warm carried assemblages with the fulfilled nuclear fuel, lava-like fuel-containing materials (LFCM); in dispersion condition (a dust and aerosols); in water solutions of salts of uranium. Fuel containing materials represent congestions glassy state masses in the form of black, brown both polychromic ceramics and pumice state pieces of grey-brown colors. Virtually

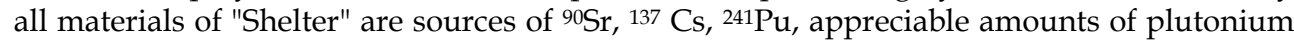
isotopes $(238,239,240 \mathrm{Pu})$, as well as ${ }^{241} \mathrm{Am}$ accumulated after the radoactivy decay of isotope ${ }^{241} \mathrm{Pu}$. Special attention found out and progressively developing intensive destruction of LFCM with formation highly dispersed "hot" particles (HP) on a surface.

It is shown, that dust generation ability of the fulfilled nuclear fuel of object "Shelter" from LFCM various type has high enough level both in the air environment, and in high vacuum. Annual total dust generation in object "Shelter" only at the expense of this mechanism it appears at level of several tens kg's of the irradiated fuel. In HP activity averages $\beta$ - and $\gamma$ activity radionuclide decrease according to a half-life period about 30 years, and $\alpha$-particles, on the contrary, increase at the expense of accumulation ${ }^{241} \mathrm{Am}$ as disintegration product ${ }^{241} \mathrm{Pu}$ additionally. HP from object "Shelter" are considered as the most radiation dangerous for biota because of the big factor of adjournment in breathe bodies (more than $40 \%$ ) and

\footnotetext{
* Kliuchnikov Olexander, Seniuk Olga, Gorovyy Leontiy, Zhidkov Alexander, Ribalka Valeriy, Berezhna Valentyna, Bilko Nadiya, Sakada Volodimir, Bilko Denis, Borbuliak Irina, Kovalev Vasiliy, Krul Mikola and Georgy Petelin Institute Cell Biology \& Genetic Engineering of NAS of Ukraine, Ukraine Institute for Safety Problems of Nuclear Power Plants NAS of Ukraine, Ukraine National University "Kyievo-Mogiljanskaja Academy", Ukraine
} 
the high radiating weighing factor (more than 20). Long track $\alpha$-emitters in a living tissue (33 to 40 microns) significantly increases the radiation dosemore than 50 times due to appearance of local foci of exposure and increased risk of subsequent development of cancer as well as non-neoplastic diseases.

Dissolution of fuel containing materials in water inside "Shelter" as the result of ability to living microorganisms, results in occurrence of new bindings radionuclide - with organic substance are potentially dangereos and more mobile. On the basis of the received experimental data the biotic factor connection with radioactive aerosols in object "Shelter" is investigated. Existence of nano- and micro- size dust as radioactive aerosols with a number of specific properties inside the object "Shelter" and absence strong barriers against entered an environment of catching filters represents high potential risk of occurrence of adverse biomedical consequences for the personnel and for ecology of a 30-km Chornobyl zone.

The complex studies living mammalian organisms and of Chornobyl zone grown plants using post genomic methodologies such as genomics, transcriptomics and proteomics might provide detailed insight into the biochemistry of living plant cells influence chronic ionizing radiation were investigated. For plant of flax the main objective of this experimental research is to elucidate molecular compare changes between plants grown during flowering and embryogenesis in contaminated and control fields in Chornobyl area.

It is shown, that cells of different types (splenocytes, hepatocytes, bone marrow and astroglia cells) obtained from irradiated mice irrespective of a mode of influence of IR (total one-time external exposure $\gamma$-radiation by $5.0 \mathrm{~Sv}$, total external exposure $\gamma$-radiation by $0.290 \mathrm{~Sv}$ for 231 days, long-term (over 74 days) incorporation of ${ }^{137} \mathrm{Cs}$ with drink accumulation in the bodies of mice radioactivity (near $18 \mathrm{kBq}$ ) produce the factors not identified in this research in addition raising levels of single strand breaks (SSB) inside DNA for non-irradiated cells. In the conditions of a single exposition in $\gamma$-fields with achievement of a dose of an external irradiation nearby $5.0 \mathrm{~Sv}$ intensity of production of «bystander» signals above at mice with the raised level of genetically determined sensitivity to response chronic irradiation. Under the same conditions of influence $\gamma$-fields sheds light an induction of additional levels of SSB in DNA not irradiated cells on an extent at least one month after IR influence. The positive dynamics of serum levels of alanine aminotransferase and antibodies to the liver-specific lipoprotein - specific poly antigen for the liver, in the accumulation of dose $0.100 \mathrm{~Sv}$ is determined in animals that are under chronic exposure. Registered data correlated with pathomorphological changes in liver tissue.

An intra peritoneum injection of melanin with melanin-glucan complex from fungus Fomes fomentarius before irradiation procedure promotes essential decrease in production of «bystander» signals and normalization of hemopoietic progenitor cells, testifying in favor of free radical nature of their certain part. It is discovered also in our experimental research would be approved in Chornobyl zone the character of morphology changes develop, flowering, mature soybean seeds and flax of plant depend of chronic irradiation, changes in signal system and epigenetic changes as appear two peaks in curve depend of flowering rate during term of vegetation for flax which treatment with melanin content solution.

The researchers could use working models on base received experimental data in order to develop approach for living mammalian cells and plants which grown under influence chronic irradiation that were withstand consequences chronic irradiation of the radionuclide contamination environment around object "Shelter". 


\section{Consequences of the Chornobyl catastrophe for the biota}

\subsection{Structure of the radiation factor in object "Shelter"}

The unique biota inside object "Shelter" during its existence was appeared. It is one more physical carrier of ionizing radiation. High humidity and positive temperatures inside "Shelter" even in winter are responsible for the formation of homogenecity thermostatic conditions favorable for the development of microorganism biocenoses. Authors [Pazuhin E.M., Krasnov V.A. \& Lagunenko A.S. 2004] have shown that the fuel-containing materials are dissolved under the action of microorganisms. As a result, new compounds of radionuclides with organic matter appeared and they are potentially more mobile and more ecologically dangerous. It was found out the microorganisms on the irradiated nuclear fuel from "Shelter" by the method of electronic microscopy. They are capability to develop on the irradiated nuclear fuel (dioxide of uranium) as a source of mineral substances and to cause the characteristic damage of a surface of nuclear fuel. In Figures 1 and 2 the characteristic damages of a surface of the irradiated nuclear fuel is found.

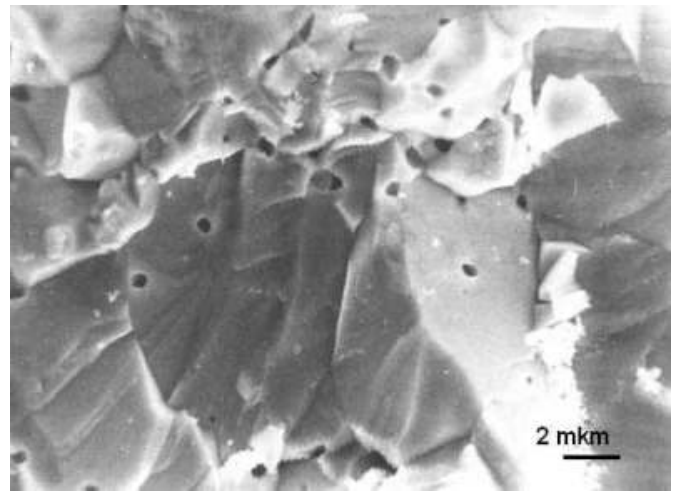

Fig. 1. Clean the surface of irradiated nuclear fuel

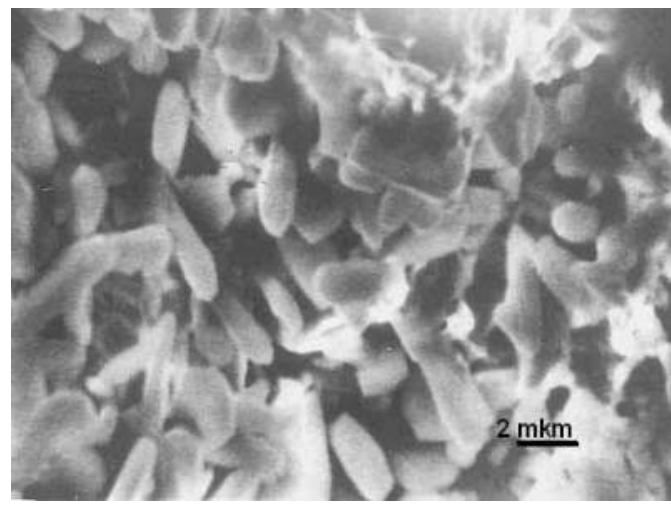

Fig. 2. Microorganisms on the surface of irradiated nuclear fuel

The size of fuel particles in the sample is in the range of 1 to $100 \mathrm{mcm}$, which corresponds to the grain size of the irradiated fuel is not oxidized. The main source of radioactivity was 
radionuclide ${ }^{137} \mathrm{Cs}$ which moved through the aerosol pathway. Practically the entire aerosol ${ }^{137} \mathrm{Cs}$ is detected in the material of organic origin fuel particles coated this organic material. Presence of radiating fields of different intensity promotes strengthening of mutational process and selection of radio-resistant microorganisms with new properties was investigated.

Dust. Using special equipment as called impactor received gas-air mixture probe samples inside object "Shelter" was determinated. This instrument allows you to separately collect particles of different aerodynamic diameters (from 9.4 microns up to 0.1 microns) of the aerosol complex structure with an uneven distribution of radioactivity. The rate of pumping of air was $70 \pm 4 \mathrm{l} / \mathrm{sec}$. The aerosol particles in the electron microscope REM-100U were evaluated. The most typical kinds of aerosol particles are represented in the Figures $3-6$.

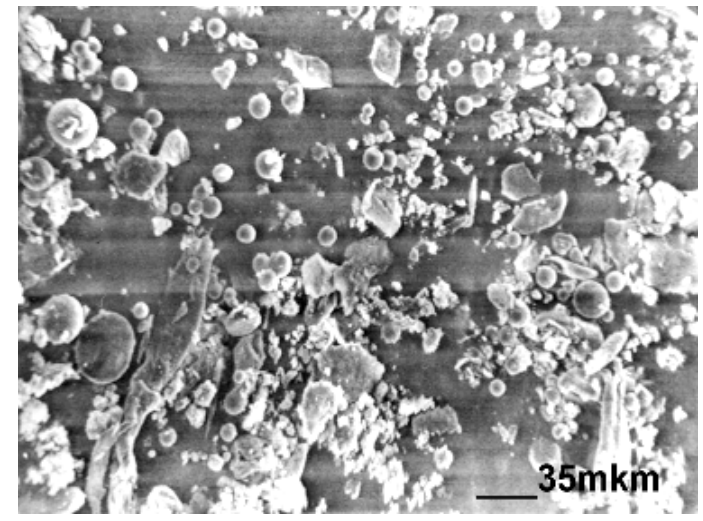

Fig. 3. The appearance of particles washed off from the first cascade impactor. The photograph shows that the aerosol is contained a large number of spherical and ovalelongated particles - bacterial spores and cocci.

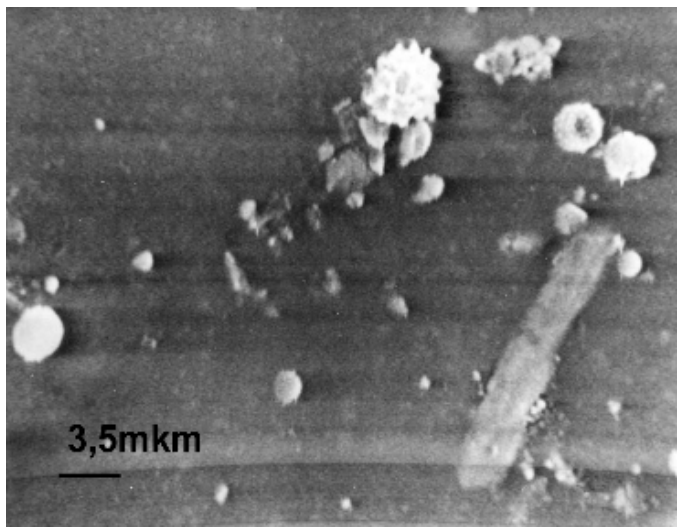

Fig. 4. Fragment the surface form the third cascade. The photograph identified particles of bacterial polysaccharide slime, as well as particles which can be produced during the destruction of microbial cells in the vacuum treatment 
The particles of the correct spherical or oval-oblong, which are easily identified (spores, cocci, etc.) [Gusev M.V. \& Mineeva L.A. 1992] and particles of irregular forms seen in presented figures. It is shown by electron microprobe elemental analysis that the major part of these particles consists of organic matter and it is of biological origined [V.B. Rybalka, G.F. Smirnova \& G.I.Petelign, 2005].

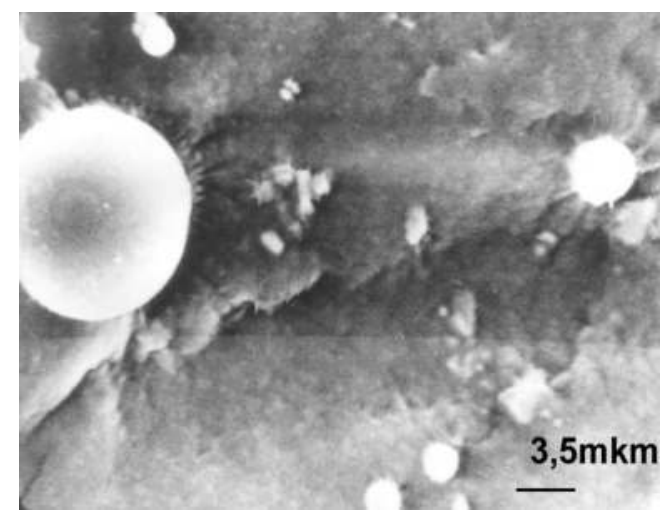

Fig. 5. The appearance of the surface of $4^{\text {th }}$ level impactor. Cocci from 10 to 2 micron and submicron particles of indefinite form are visible

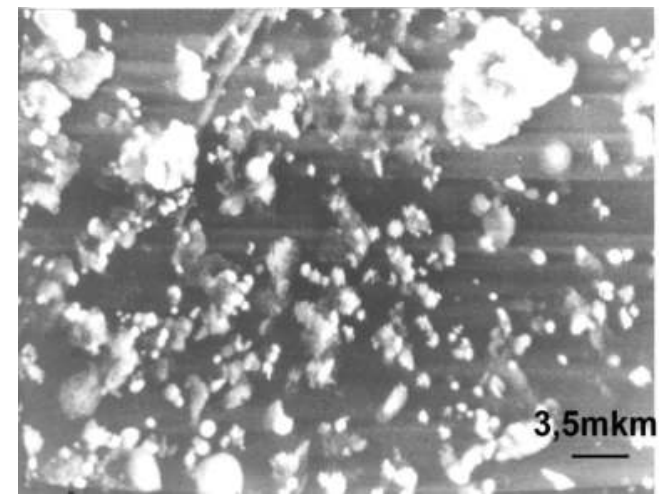

Fig. 6. The appearance of the surface of $4^{\text {th }}$ level impactor. It is seen a large number of particles that are aggregates of loosely coupled small particles

Thus, there are a large number of particles consisting of organic matter in the investigated samples of aerosols originated from "Shelter" premises. A significant number of these particles are identified as the cells of microorganisms and spores.

Sub-micron hot particles (smHP) There is high-dispersive hot particles, which needs a special attention. Such kind of particles is a product of spontaneous dust productivity phenomenon which means dust generation from surfaces of irradiated nuclear fuel and LFCM surfaces. Such a phenomenon was discovered experimentally [Baryakhtar V.G., Gonchar V.V. \& Zhidkov A.V. 1997] and for irradiated fuel was confirmed in [Walker C. 2000] later. The smHP grade distribution and possible physical mechanisms responsible for it was later 
identified in [Baryakhtar V., V.Gonchar \& Zhidkov A. 2002]. Typical particle grade is 150 $\mathrm{nm}$ for fuel HP and near $50 \mathrm{~nm}$ for LFCM particles; all the particles have a complicated internal structure [Baryakhtar V., Gonchar V. \& Zhidkov A. 2002]. Their radionuclide composition and specific radioactivity does correspond to those for FCM [Baryakhtar V.G., Gonchar V.V. \& Zhidkov A.V. 1997]. Such kind of HP practically cannot be trapped by standard respirators, which usually at personnel's disposal. Annual estimated activity generated in a form of such kind aerosol does equal to a few tens kilograms of irradiated fuel [Baryakhtar V.G., Gonchar V.V. \& Zhidkov A.V. 1997].

Such sub-micron HP (Figures 7,8 ) to be considered as the most dangerous radiationhazardous agent regarding to a few reasons: their behaviour in biological liquids is similar to those for the particles in true liquid solutions, smHP does not need solubility of fuel matrix for penetrating all natural biological barriers originated from cell membranes. Submicron HP aerosol provides near $80 \%$ of total inhalation dose and to be an agent determining effective dose formation for "Shelter" object personnel [Bondarenko O.A., Aryasov P.B. \& Melnichuk D.V. 2001]. Existing national regulatory documents on radiation safety does not establish a tolerable concentration of such kind aerosols in the "Shelter" object atmosphere because any attempt to classify them (in accordance to accepted classification) turned out to be doubtful. There are, however, explanations in regulatory document СПРБ-ОУ (in Ukrainian) (Appendix 1), which prescripts what should be done when real aerosols characteristics differs from the typical ones. According to that document, when planned activity stipulates thermal or chemical impact on FCM congestions or heavily contaminated "Shelter" object elements and when revealing in aerosols of non-oxide uranium or TUE chemical compositions one should establish the tolerable concentration for a- and $\beta$-emitters in air basing on results of additional special investigation.

Water of the lower marks and technological waters Shelter. It was established that concentration of $\gamma$-emitting radionuclides reaches $3.8 .10^{11} \mathrm{~Bq} / \mathrm{l}$, while the concentration of uranium measured up to $0.3 \mathrm{~g} / 1$ in several thousand cubic meters of "block" and the technological water in premises of lower marks. These water accumulations influence the state of nuclear security of the object "Shelter". They may lead to a change in breeding properties of system "FBM + fragments of the core + water" and the emergence of emissions of short-lived radioisotopes such as iodine. This radionuclide is known to cause the spectrum of thyroid diseases, including cancer.

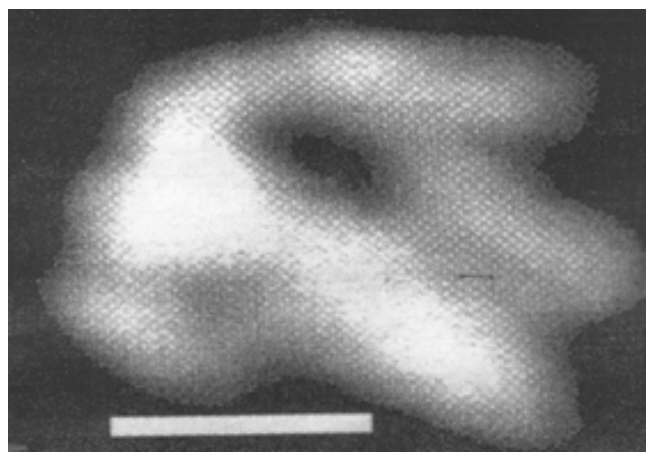

Fig. 7. Dust particles complicated internal structure, formed in the fuel-bearing materials. The length of the white line $-80 \mathrm{~nm}$. 


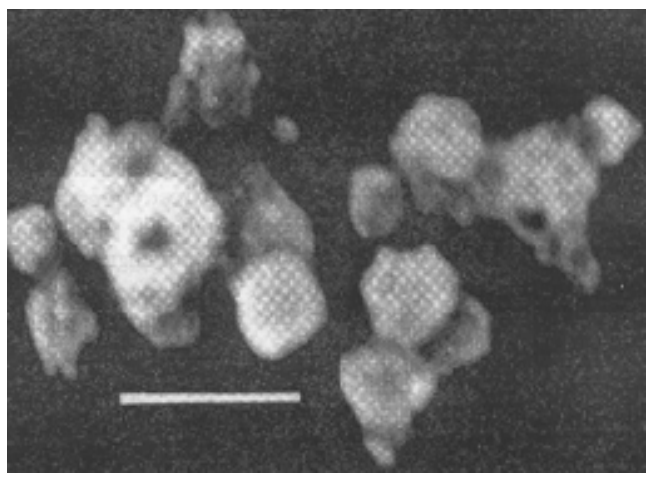

Fig. 8. Spontaneous destruction of the fuel particles to the submicron particles of "hot particles" as a result of processes of radiation defect in the fuel-bearing materials. The length of the white line $-80 \mathrm{~nm}$.

The concentration of radioactivity elements occurs in the silts as the drying pools during the summer-autumn period. Thus silts in "Shelter" represent a real risk as a source of radioactive aerosols. Different kind of microorganisms are found in water accumulations at zero marks of "Shelter" - bubbler pool (Figures 9 - 12) and on the surface of the walls (Figures 13 - 16) [Rybalka V.B., Rybalko S.I. \& Zimin Yu.I. 2001, Zhdanova N.N., Zaharchenko V.A. \& Tugaj T.I. 2005, Rybalka V.B., Smirnova G.F. \& Petelin G.I. 2005, Petelin G.I., Zimin Yu.I., Tepikin V.E. 2003, Rybalka V., Klechkovskaja E., Serbinovich V. 2001]. The experimental investigation of water samples of the Shelter are presented in Figures 9 - 13.

As follows from figures 9 and 10, in the waters of the Shelter are present microbial community in various forms and sizes. In some samples well-reviewed spores size of about 0,1 micron. There is a large number of different units and formations. The biomass of the samples has a very high level of specific activity $\left({ }^{137} \mathrm{Cs}\right.$ to $3,9 \times 10^{10} \mathrm{~Bq} / \mathrm{m}^{3}$; ${ }^{90} \mathrm{Sr}$ to $7,9 \times 10^{9}$ $\mathrm{Bq} / \mathrm{m}^{3},{ }^{238+239+240} \mathrm{Pu}$ to $\left.1,1 \times 10^{5} \mathrm{~Bq} / \mathrm{m}^{3}\right)$.

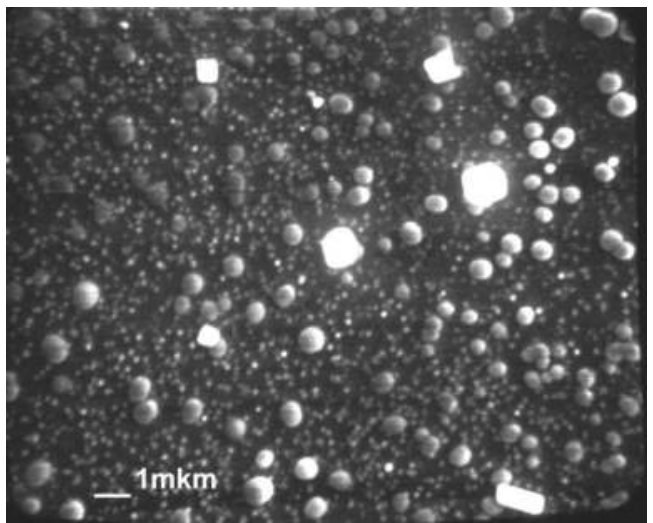

Fig. 9. The appearance of content drops of water from bubbler pool. 


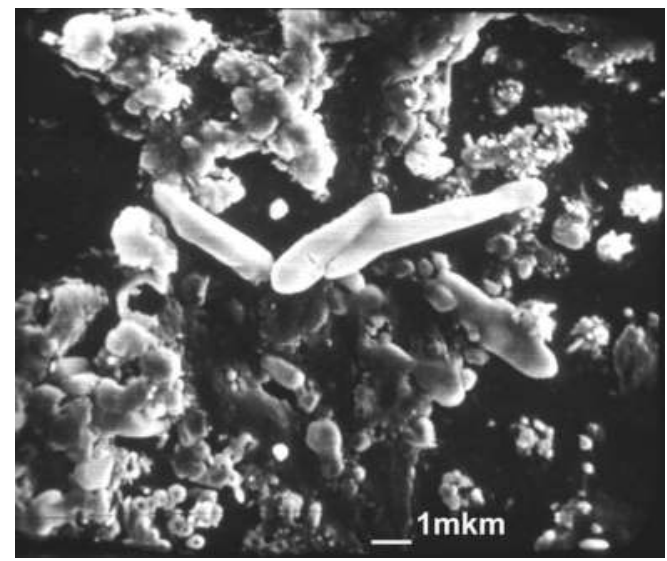

Fig. 10. The appearance of content drops of water from bubbler pool.

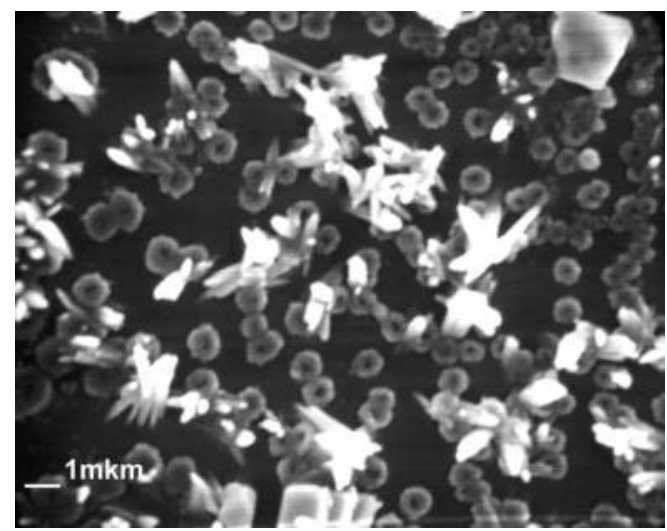

Fig. 11. The appearance of content drops from water from bubbler pool.

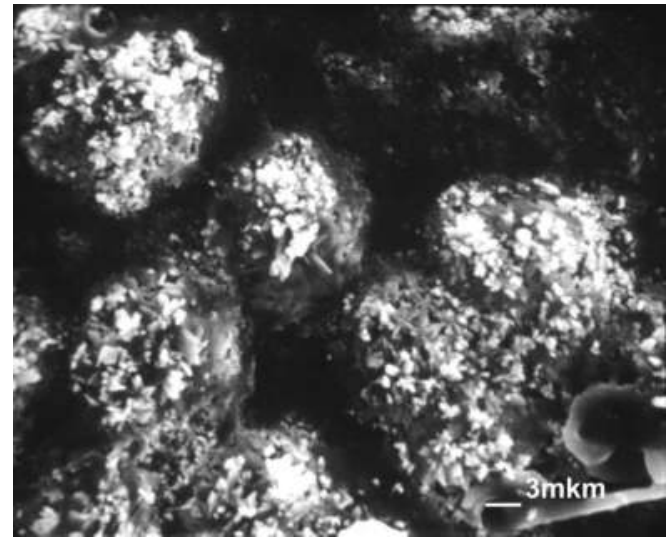

Fig. 12. The appearance of content drops from water "Shelter 


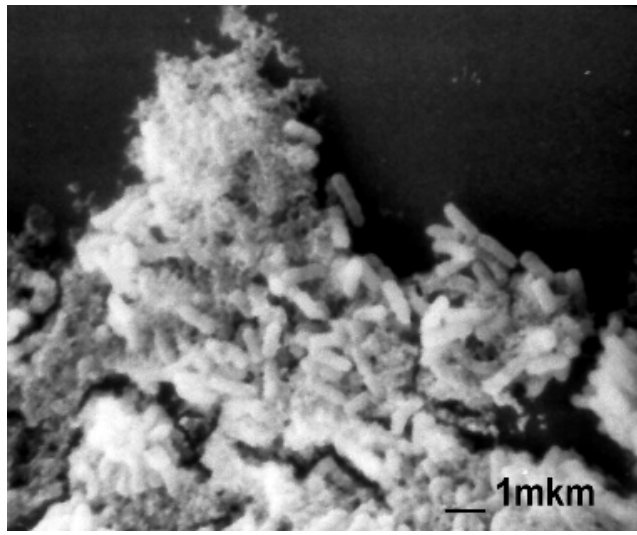

Fig. 13. The appearance of content drops of water from bubbler pool.

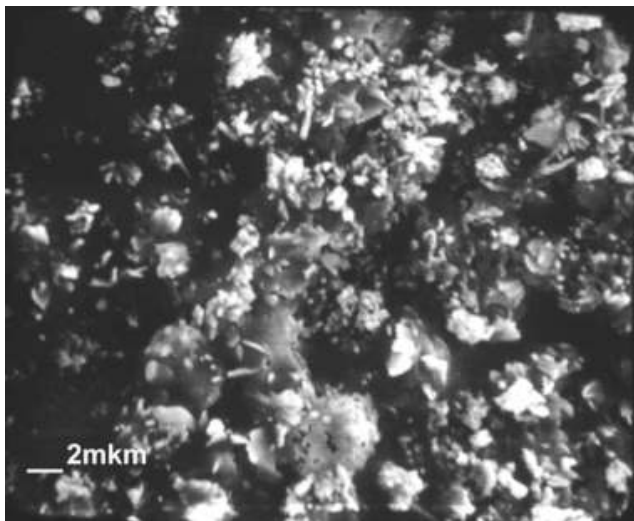

Fig. 14. The appearance of content drops of water from bubbler pool.

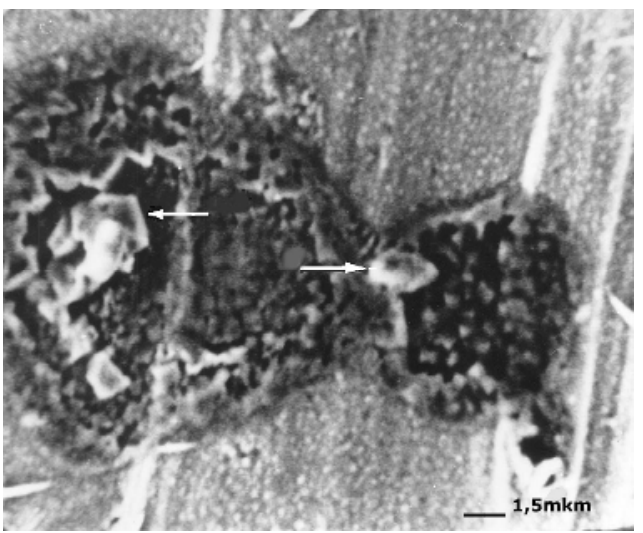

Fig. 15. The fuel particles from swabs from the walls after the burning of organic matter in a vacuum. 


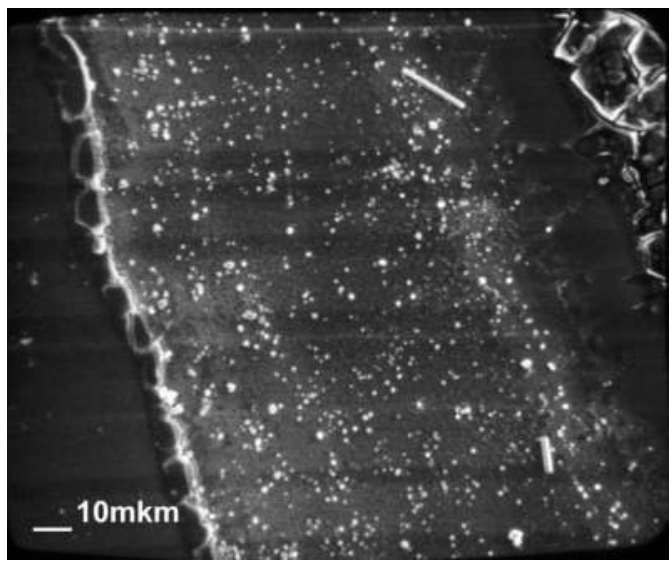

Fig. 16. The appearance of the microbes isolated from swabs of material from the walls after drying a drop of suspension on the glass

Microscopic siza fungi widely exist in the microbiota of the Shelter together with bacteria represented. It is shown that the defeat of microscopic fungi growing in areas with low levels of contamination (from one to $100 \mathrm{mR} / \mathrm{hr}$ ) [Zhdanova N.N., Zakharchenko V.A. \& Tugay T.I. 2005]. The life-cycle reduction, increased radioresistance, increasing the frequency of occurrence of positive radiotropic reactions and radiostimulation, high photosensitivity, that correlated with radiotropic response are typical for fungi-extermophyles isolated from such premises. In these premises increasing the risk of fungal biodegradation, increasing the probability of development of active agents of onychomycosis, skin lesions, lung infections, otitis, invasive fungal infections, as well as the selection of radio resistant organisms with unpredictable invasive characteristics. Lack in human natural immunity to these microbes, resistance of new cultures to the action of traditional medicines, high-speed distribution of microbes (biomass doubling from 15 minutes to 2 hours), the possibility of "transfer" the genetic information with hazardous properties to other bacteria, protozoa, algae, fungi and higher organisms can provide a very serious threat for people. It is known that in the light roof of sarcophagus has a large number of defects and inside the "Shelter" are circulating constant vertical wind currents. So it is quite realistic assumption that some of these microorganisms, especially in the form of spores, can potentially overcome the filters and act to the respiratory tract and lungs of people working inside this object at one side and at another side may carry away outside "Shelter".

\subsection{Elucidation of radiobiological effects that can influence the formation of the structure of morbidity}

The small doses of radiation can increase the likelihood of developing cancer [Brenner D.J., Doll R. \& Goodhead D.T. 2003, NCR 2006] and is possibility appearing morbidity non-cancer origin [Hildebrandt G. 2010]. The main outcome of the 25-year study of morbidity in different categories of exposed persons in connection with the Chernobyl catastrophe is a significant increase in primary morbidity is not associated with tumor pathology. Not found increased risk of leukemia even among those engaged in reconstruction work. Only recently become apparent relationship of radiation exposure 
with increasing number of non-oncological pathology such as cardiovascular diseases [Preston D.L, Shimuzu Y. \& Pierce D.A. 2003]

Statistically significant increase in the spread of non-neoplastic diseases is shown in [Bouzounov O.V., Tereshchenko V.M. 2010]. At the same time structure of morbidity leading place is occupied by diseases of digestive, circulatory and nervous system The maximum level and the largest number with the non-neoplastic diseases statistically confirmed by link determined in the dose $>0,25 \mathrm{~Gy}$ for subcohort study group. Long-term effects of chronic low-intensity exposure to low doses for exposed persons in this category until the end is unclear.

The rapid growth of non-tumor morbidity in exposed populations reflects certain changes in the systems that control the growth, development and aging, namely stereotypes matching sequence and intensity of reading the genetic information in different cells. It is shown that this task cannot perform any neural mechanism, or hormonal agents with their ability to alter the rate of metabolic processes. Neurotransmitters, hormones and their receptors do not possess sufficient ontogenetic variability and dispersal [Poletayev A.B. 2008].

According to modern ideas exactly a physiological autoimmunity throughout life provides a readout of genetic information in different cells of the whole organism [Churilov L.P. 2008, Maltsev V.N. 1983, Zaichik A.Sh. \& Churilov L.P. 2008]. Singularity of the function of autoantibodies ( $\mathrm{AuAB}$ ) compared with other regulatory substances is considerably longer their half-lives ranged from 10 to 50 days. Therefore the system of autoimmunity has greater inertia. Autoantibodies regulate slow the physiological processes that continue some days and weeks [Ashmarin I.P., Freidlin V.P. 2005]. It is postulated that a mild autoimmune response to their own antigens is a necessary condition for the normal functioning of the immune system and is a prerequisite for the normal regulation and synchronization of cellular functions and morphogenesis [Churilov L.P. 2008]. Additional conditions for unmasking antigens of tissues and organs and represent them immune cells with subsequent increased production of specific $\mathrm{AuAB}$ appear as a result of exposure to ionizing radiation.

It is well known that oxygen absorbed by the mitochondria is converted into adenosine triphosphoric acid (ATP). About 5\% of oxygen consumed by tissues is converted into free radicals such as superoxide, hydrogen peroxide, hydroxyl radical, singlet oxygen, peroxynitrite (reactive oxygen species, ROC) with unpaired valence electrons. Most of the ROS are produced continuously in cells as byproducts of normal cellular metabolism (mainly due to a small leakage of electrons to the mitochondrial respiratory chain, as well as other reactions in the cytoplasm), and do not cause damage to cells. An excess of ROS under intense ionizing radiation exceeds the protective capabilities cells and can cause serious cell disorders (eg, depletion of ATP). The increase of free radical molecules and their products have a place in the development of the state of homeostasis, has been called oxidative stress. Slow development of oxidative stress triggers apoptosis, and its intensive development leads to necrosis. Postradiation apoptosis is characterized by maintaining the integrity of the cell plasma membrane and the lack of exposure of intracellular contents from cells of the immune system. In the end, remnants of apoptotic cells are removed by exfoliation in intraorganic space and subsequently excreted from the body. But the shortage of ATP, in particular after irradiation, the energy dependence of the mechanisms of apoptosis are disabled, and the cell dies with loss of cell membrane integrity and release of macromolecular 
components (eg, ALT, AST, etc.) into the intercellular space. Necrosis caused an immune response in the form of inflammation - leukocyte infiltration of the affected tissue, interstitial fluid accumulation and subsequent induction of specific immune responses (specifically sensibilized T-lymphocytes and autoantibodies) to the unmasked and recognized by lymphocytes of intracellular components. According to data of many researchers the AuAB are primarily the attribute of the norm. They can be identified in healthy individuals. [Churilov L.P. 2008, Zaichik A. Sh. \& Churilov L.P. 2008b, Poletayev A.B. 2005, Cohen I.R. 2005, Harel M. \& Shoenfeld Y. 2006, Shoenfeld Y. 2008]. The AuAB involved in the process of apoptosis, cleaning the body from catabolic products, modulation of the activity of many enzymes and hormones, as well as perform the transport function [Poletayev A.B. 2008a]. It was shown that antibodies against nuclear antigens can penetrate into the cell nucleus in vivo and stimulate the synthesis of RNA and DNA in target cells [Zaichik A. Sh. \& Churilov L.P. 1988].

Notkins in 2007 hypothesized that natural AuAB can be very informative not only precursors of autoimmune diseases, but also a variety of somatic diseases and syndromes [Notkins A.L. 2007]. It is important that changes in the content of organ natural AuAT in most cases, ahead of the clinical manifestation of appropriate forms of pathology. If for example the content of "cardiotropic", hepatotropic", "neurotropic" AuAB a concrete person within the borders of the norm, this suggests that the intensity of apoptosis, respectively, cells of the heart, liver or nerve tissue does not go beyond the norm. Persistent changes, for example, from "hepatotropic" AuAB should be regarded as a sign of the possible formation of a pathological process in liver tissue, even if at the time of examination are no clear clinical symptoms or specific biochemical changes [Poletayev A.B. 2008a, Churilov L.P. 2008, Notkins A.L. 2007, Zedman, A.J.W. \& Vossenaar E.R. 2004].

The important role of the abolition of immune tolerance in the occurrence of non-viral hepatitis research shows serum levels of antibodies to liver-specific lipoprotein (LSP) for various categories of people. [Kovalev V.A. \& Senyuk O.F., 2008].

The LSP which was first isolated by Meyer zum Burschenfelde and Miescher in 1971 is considered to be specific poly antigen for the liver. Native LSP is mixture of antigenic determinants of the substrate from the membranes of hepatocytes and contains soluble and membrane components were isolated by gel filtration (chromatography) supernatant after ultra- centrifugation of liver homogenate [Manns M, Gerken G. \& Kyriatsoulis A, 1987, Ballot E., Homberg J. C. \& Johanet C. 2000]. It is known that LSP is found not only in the liver, but also in some other organs [Garcia-Buey., Garcia-Monzon C. \& Rodriguez S. 1995]. Therefore, the total increase in antibody levels to the PSL can be seen as a sign of abolition of immune tolerance to many organs and tissues of the human body [Kovalev V.A. \& Seniuk O.F., 2008].

There are three outcomes for the cell, if the cellular radiation damage is not adequately repaired. The cell may die, or will delay it or keep playing with the viability of new qualities, or mutations as the basis for the development of remote descendants (See figure 17). The consequences of the first approach in the development of cells after irradiation described below.

The linear non-threshold concept is used as the primary standard for radiation protection and risk assessment for many years. It suggests that damage induced by low doses of radiation do not contribute significantly to increased risk of disease because a significant 
amount of endogenous genome damage occurs during life and they are restored in cells with high probably. In fact endogenous damages (ED) constantly appear in the cells. Some of them are due to thermodynamic processes, the hydrolysis reaction, while others arise from the effects of free radicals generated by cell during its life and still others are a necessary component of metabolism (DNA breaks accompany the process of differentiation, recombination, etc.) [Lindahl T. 1993, Bont R.D. \& Van Larebeke N. 2004]. According to [Lindahl T., 1993] per one day in the DNA of one cell may have more than 50,000 endogenous damages as single-strand breaks (SSB) and 10 ones as double-strand breaks (DSB).

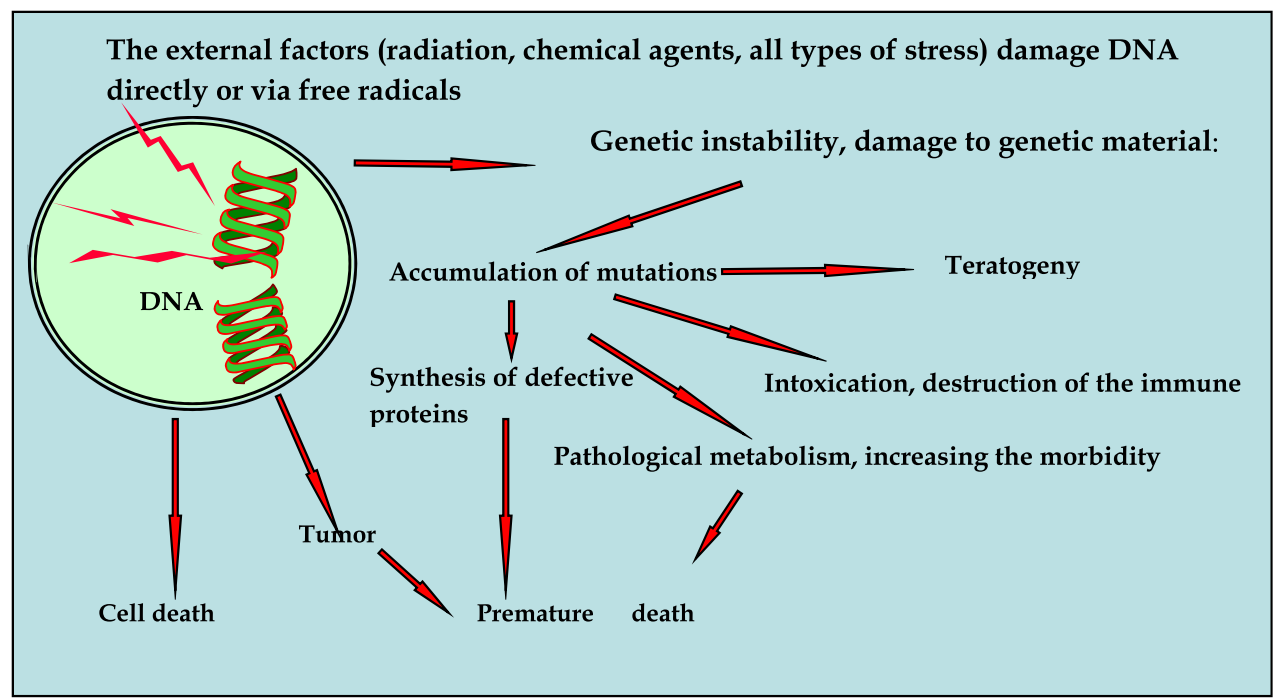

Fig. 17. Effects of radiation exposure on the genetic apparatus of cells.

Many studies suggest that most of the radiation damage (RD) occurring in the DNA of cells differ significantly in their chemical nature from the ED. The main difference between DNA damage induced by ionizing radiation, from the ED was its the complexity of their chemical nature, and clustering. The proportion of complex, critical for the fate of the cell damage is much higher when exposed to IR.

When treatment of mammalian cells to $\mathrm{H}_{2} \mathrm{O}_{2}$ ratio of DSB to SSB is 1: 10000 [Bradley M.O. \& Kohn K.W. 1979] while under the influence of IR is much higher -1:20 [Shikazono N., Noguchi M., \& Fujii K. 2009]. Many of the DNA RD are not accidental, are located in close proximity and have the cluster grouping. They are formed as a result of coincidence of two or more single damages within 1-2 rotation the DNA helix [Hada M., Georgakilas A.C. 2008, Sutherland B.M., Bennet P.V. \& Sidorkina O. 2000]. Especially the massive clustering of DNA damage occurs when the ionization tracks pass along chromatin fiber. In this case, they may cover DNA regions with an average size of about 2000 base pairs [Radulescu I., Elmroth K. \& Stenerlow B. 2004]. At the same time, we know that the probability of occurrence of endogenous clustered DNA damage is extremely low [Bennett P.V., Cintron N.S. \& Gros L. 2004]. Accumulation of ED does not occur because in the cells are constantly functioning mechanisms of reparation, specifically targeted at removing various types damages [Friedburg E.C., Walker G.C. \& Siede W. 2006]. 
The complex nature of RD of DNA and the presence of cluster groups can be regarded as the first cause, which creates difficulties for repairing systems cells. Damages repair processes within the cluster can break down in various stages of excision repair and lead to the formation of additional or inaccurate DSB repair, important for cell survival, mutagenesis, and the risk of malignancy [Ide H., Shoulkamy M.I. \& Nakano T. 2010]. The second reason for the low efficiency of repair of RD may be a relatively low amount of DNA damage. Therefore, radiation effects in low dose range and low power are certain features associated not only with destructive modifications but with deducing the cellular genome at a different level of activity. High doses of ionizing radiation via activation of cell cycle control points - checkpoints, blocking the synthetic phase of the cell cycle (S) and the transition from $G_{1}$ to $S$ phase and $G_{2}$ to $M$ (mitotic) phase and support the repair of DNA. In this case, small doses can not activate the $\mathrm{G}_{2} / \mathrm{M}$ chekpoynt-arrest and DNA repair are not activated when the number of DSB DNA damage and the MNF up to 10 - 20 per cell.

In this case, heterochromatin little relaxes, and access of repair enzymes to sites of DNA damage worsens [Fernet M, Megnin-Chanet F. \& Hall J. 2010, Grudzenskia S., Rathsa A., Conrada S., 2010, Marples B., Wouters B.G. \& Collis S.J. 2004, Gaziyev A.I. 2011]. There is the third of the possible causes of low efficiency of repair of critical DNA damages.

The major part of radiation induced DNA damages are represented by DSB and crosslink between strands, which slowly and inefficiently repaired and are responsible for various end effects - from the radiation death of cells to the appearance of chromosome aberration, gene mutations and neoplastic transformation. [Pfeiffer P., Gottlich B. \& Reichenberger S. 1996]. Therefore radiation effects in low dose range and low rate dose have the certain features associated not only with destructive changes than with deducing the cellular genome at another level of activity. Analysis of many studies suggests that DNA damage caused by the IR, increase linearly with dose, but the reaction of cells on these lesions, the efficiency of repair of the most complicated critical damages can be nonlinear. Because irradiation is decreased expression of proteins, enzymes of different systems providing the stability of DNA as a result of the accumulation of DNA damage is not recovered or recovered with errors and fix mutations. Dysfunction of many genes, regulatory systems and cellular processes that are ultimately linked to the development of various pathologies, including carcinogenesis. A significant part of replication errors - spontaneous mutations - can be harmful to an organism. There are the basis for the occurrence of hereditary diseases, carcinogenesis, etc. were revealed.

\subsection{The study of the radiological effects of low and middle doses in model experiments on linear animals}

It is known that some of the surviving cells after irradiation can produce functionally modified descendants, who have for many generations with a high frequency occur de novo chromosome aberrations and predominantly point mutations, in certain cases increase cell death by apoptosis [Little J.B. 2000, Seymour C.B., Mothersill C. \& Alper T. 1986, Baverstock K. 2000]. The accumulation of such mutations suggests a high probability disorders in the bases caused by oxidative stress [Little D.B. 2007]. It is known that even in non-irradiated cells residing in close proximity to irradiated cells, induction of chromosomal instability is possible.

Placing of non-irradiated cells (NirC) in the culture medium of irradiated cells ( $\operatorname{IrC})$, soon leads to the appearance in the descendants of (NirC) of chromatid and chromosome aberrations, micronuclei, gene mutations that increase the content of the transformed cells 
[Pfeiffer P., Gottlich N. \& Reichenberger S. 1996, Seymour C.B., Mothersill C. 1997, Johansen C.O. 1999]. The phenomenon of transfer of an altered state from the modified cells under damage factors to unmodified cells was named "bystander effect" (BSE). It was first described in Chinese hamster [Nagasawa H, Little J.B. 1992] cells and was later found in different types of cells after exposure to damaging factors of different nature [Azzam E.I., Little J.B. 2003, Azzam, E.I., de Toldeo, S.M. \& Little, J.B. 2003, Chakraborty A, Held K.D. \& Prise K. 2009, Mothersill, C \& Seymour, C. 2001]. Thus, cells that have not been laid through the tracks of IR are "bystanders" of radiation injuries caused by other irradiated cells. Reactive oxygen species (ROS) play an important role in the mechanisms of signal transmission to "bystander" cell [Kudryashov Yu.B. 2004]. Reinforced ROS production in NirC incubated in medium with serum, irradiated a-particles, or with supernatant of the suspension of IrC [Narayanan P.K., Googwin E.YH, Lehnert B.E. 1997] or after contact by IrC [Grosovsky A.J. 1999] is shown.

Irradiated cells produce several "bystander" signals - cytokines, fragments of DNA (from apoptotic cells) or other factors of protein nature. These factors cause a change in oxidative metabolism and gene expression profiles in $\mathrm{IrC}$, and induce enhanced production of highly ROS [Watson G.E., Lorimore S.A., Macdonald D.A., 2000, Ermakov A.V., Kon'kova M.S., Kostyuk S.V. 2009, Snyder A.R. 2004, Lorimore S.A., Coates P.J., Scobie G.E. 2001]. In addition to chemical modification of DNA nucleotides the formation of radicals can also lead to changes in the higher levels of organization structure of the molecule to the secondary, tertiary and quaternary conditions [Nobler M.P. 1969]. Therefore the level of oxygen and antioxidants influence the quantitative yield and quality of damaged bases of DNA in IrC.

Signal transmission of such lesions through the culture medium is typical for BSE induced by IR from low linear energy transfer [Mothersill C., Seymour C.B. 1998]. In our study we used a hypothesis about the ability of $\gamma$-rays to generate in a organism of mammals part of "bystander" signals that can be distributed in the environment of the body and affect distantly unexposed tissue. At the same time we take as an axiom that some of these of signals has a free radical nature, in particular, can be represented by the ROS. Scheme of the origin and development of BSE corresponding to this hypothesis is shown in Figure 18.

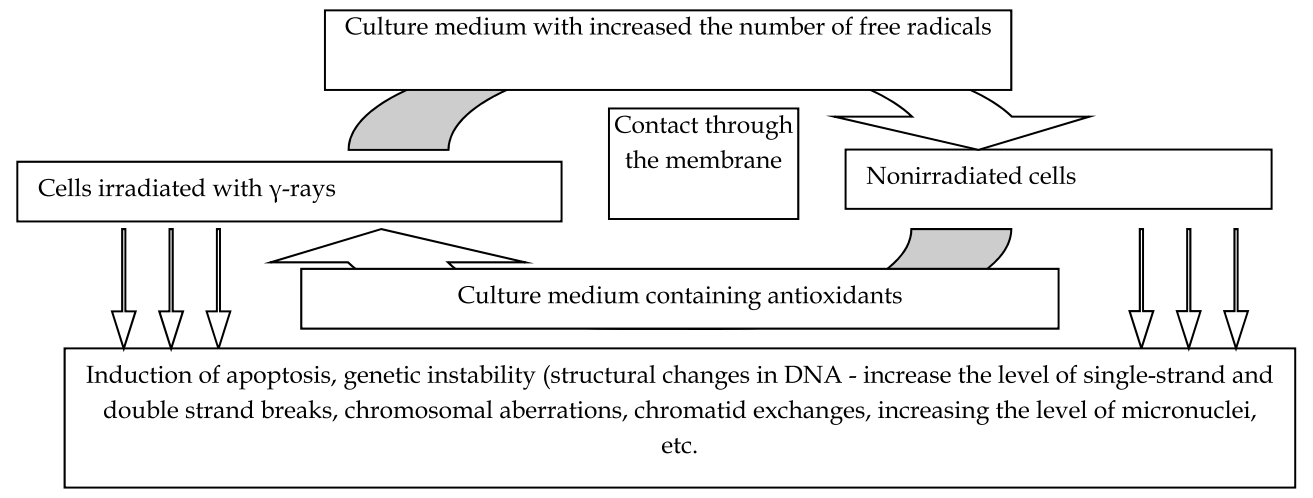

Fig. 18. Elucidation scheme of the experiments 
We used a biological model, which allows you to multiply the amount of cellular material to strengthen the "bystander" signals in the intercellular space. For this purpose females of mice Balb/c and C57bl/6 were irradiated. It is known that mice C57Bl/6 is moderately sensitive to ionizing radiation, $\mathrm{LD}_{50 / 30}=6.70 \mathrm{~Sv}$, and $\mathrm{Balb} / \mathrm{c}$ line of mice is highly sensitive to IR, $\mathrm{LD}_{50 / 30}=5.85 \mathrm{~Sv}$ [Blandova Z.K., Dushkin V.A. \& Malashenko A.N. 1983, Storer J.B 1966]. After exposure to $\gamma$-fields from organs and tissues of the mice (peripheral blood, spleen, liver, bone marrow and brain - astroglia) cell suspensions were obtained.

\section{Protocol modes of mice irradiation:}

1. Total one-time 16-hour exposure $\gamma$-radiation from small samples of nuclear fuel IV unit of ChNPP modified during the accident in 1986, which were evenly distributed under the cages with the exhibited animals (30 mice per line) and formed a fairly uniform horizontal $\gamma$ - field with the exposure dose rate of about $8.7 \cdot 10^{-4} \mathrm{~Gy}$ sec, allowed to reach a total dose of about $5.0 \mathrm{~Sv}\left(85 \%\right.$ of the $\left.\mathrm{LD}_{50 / 30}\right)$.

2. The total external $\gamma$-radiation exposure from a specially constructed flat concrete bars, containing soil from the Red Forest with a specific activity of $30 \mathrm{kBq} / \mathrm{kg}$ and creating exposure power $\sim 52.2 \mathrm{mcSv} / \mathrm{h}$. They were placed under cages with animal at 231 days. Total external dose was about $0.29 \mathrm{~Sv}$. Radioactive soil we previously burned for the destruction of organic compounds.

3. Long-term (over 74 days) incorporation of ${ }^{137} \mathrm{Cs}$ with a drink (at the rate of $6.0 \mathrm{kBq}$ per mouse per day) led to accumulation radioactivity from 14 to $24 \mathrm{kBq}$ in the mouse body, which was identified in the $\gamma$-spectrometer CP-4900V (Nokia, Finland). The average total estimated activity was $17.0 \pm 1.0 \mathrm{kBq}$ per animal.

\section{Identification model of "bystander" signals}

Replacing the living environment of mice

Non-irradiated and irradiated cells obtained from organs and tissues of mice kept in a nutrient medium RPMI-1640 supplemented with 5\% syngenic serum for 3 hours, after that the NirC placed in culture medium of IrC (Figure 19)

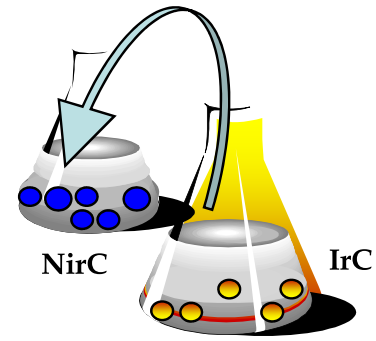

Fig. 19. Scheme of reproduction "bystander effect" in the transmission of signals through the culture medium.

We evaluated the ability of the culture medium of exposed animal cells to induce an increased number of single-strand DNA breaks (SSB DNA) in the same cells obtained from unexposed animals. Level of SSB DNA in vitro in different kind of obtained cells was determined using the method described of labeling of DNA by fluorescent dye picogreen 
with subsequent evaluation of the rate of its splitting [Elmendorff-Dreikorn K., Chauvin C. \& Slor H. 1999]. Results were presented as the coefficient of unwinding of the DNA helix (SSF), which was calculated at 20-minute exposure the DNA double helix (dsDNA) with untwine the buffer as follows:

$$
\mathrm{SSF}=\log (\% \text { dsDNA in sample } / \% \text { ds DNA in the control). }
$$

\section{Confirmation of participation molecules free-radical nature in the transfer of "bystander" signals}

Melanin-glucan complex (MGC) received from higher basidiomycetes Fomes fomentarius, was used as an antioxidant to confirm the involvement of molecules of free-radical nature to the transmission of signals from IrC to NirC after external influence of $\gamma$-rays (the model of the single and chronic exposure of mice).

Melanins are amorphous pigment of dark brown and black, they are widespread in nature and are found in virtually all groups of organisms. Melanins contain carboxyl, carbonyl, hydroxyl, amine and phenol functional groups. Because of this molecule melanin can simultaneously interact with both anions and cations with, ie to be donors or acceptors of free (See Figure 20) electrons and thus carry out electron transport functions. Melanin is also able to absorb photon's energy [Riley P.A. 1997]. These substances are characterized by the presence within their structure of unpaired electrons and possess the properties of stable free radicals. Melanin is not only absorb a variety of radiation, but also neutralizes and eliminates harmful for the cells of free radicals formed under action of ionizing radiation and some chemical substances on living organisms.

Study protector ability of microorganisms the presence of melanin in them almost all the basic mechanisms of reparative DNA repair revealed. Experimental results showing the increase in DNA polymerase and DNA ligase activity melanin mushrooms under UV irradiation were obtained by [Sidorik E.P., Druzhina M.O. \& Burlaka A.P. 1994]. Melanin pigment has a high gene protective activity in acute exposure to ionizing radiation in a wide range of doses. It was established that melanin effectively reduces the frequency of mutations induced by ionizing radiation in both somatic and germ cells [Mosse I.B. 2002]. Ability of melanin to reduce almost to control level frequencies to genetic lesions, which are transmitted from generation to generation and accumulation in populations in the form of "genetic load" is unique [Mosse I.B., Lyach I.P. 1994]. For the first time is shown the principle possibility of effective protection of animal populations irradiated over many generations by means of melanin (in Drosophila studied 150 generations, in mice - 5) [Mosse I.B., Dubovic B.V. \& Plotnikova S.I. 1996]. Radioprotective efficiency of melanin was higher in the chronic exposure than for acute irradiation conditions [Mosse I.B., Kostrova L.N., \& Dubovic B.V., 1999]. Daily oral administration of melanin in a dose of $10 \mathrm{mg} / \mathrm{kg}$ to pregnant females rats eliminated the functional deficiency of physical and emotional development, detectable in the progeny at the antenatal $\gamma$-irradiation at a dose of 1.00-1.25 Gy for the entire period of pregnancy. Conclusion of the radioprotective effect of melanin on cytogenetic and embryotoxic effects of low doses of ionizing radiation have been done on the basis of the data [Mosse I.B., Zhavoronkov L.P. \& Molofey V.P. 2005]. Melanins are capable of forming complexes with metals, including radioactive elements. The ability of synthetic melanin to accumulate radioactive elements such as ${ }^{111} \mathrm{In},{ }^{225} \mathrm{Ac}$ and ${ }^{213} \mathrm{Bi}$ had shown [Howell C.R., Schweitzer A.D. \& Casadevall A. 2008]. The possibility of the creation of radioprotective agents on the basis of melanin in the result of research was mentioned [Dadachova E, Ruth 
A. \& Bryan R.A. 2008, Schweitzer A. D., Robertha C. Howell R.C. 2008]. For our experiments used the melanin-glucan complex whith a large number of paramagnetic centers $(17 \bullet 1017$ spin/g). This substance shows armipotent antioxidant properties in interaction with various types of free radicals [Seniuk O., Gorovoj L. \& Zhidkov A. 2005].

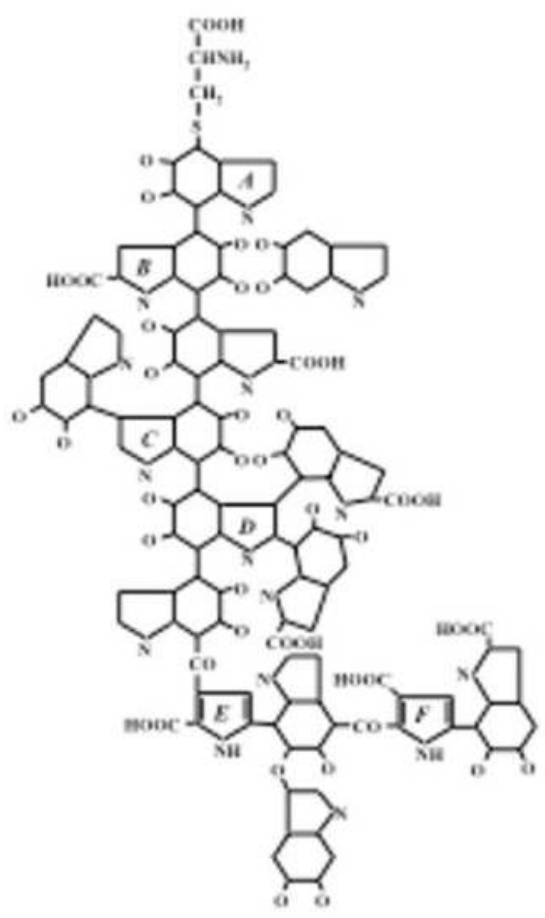

Fig. 20. The structural formula of one of fungal melanin by [Riley P.A. 1997].

Results of the study remote signaling between cells in the external effects of prolonged $\gamma-$ radiation

The first attempts to search for distant signals generated by irradiation in vivo cells were taken from Balb/c mice that have known greater sensitivity to the action of IR. Quantitative analysis of DNA damage in a mammalian cell immediately after exposure to IR with low LET in a dose of $1 \mathrm{~Gy}$ has shown that it generates approximately forty DSB and MPS (DNADNA) 150 DNA-protein crosslinks about 2000 modification bases around 3000 AP-sites of damaged deoxyribose residues, SSB and alkali-labile sites [Von Sonntag C. 2006, Ward J.F. 1988]. It is believed that the sharp increase in single-strand DNA breaks (SSB) is directly correlated with the number of DSB. The ratio of SSB to DSB under the action of IR can correspond to the values 10 - 50 depending on exposure conditions and cell types of radiation [Oxidative Stress 1991]. Indicator of SSB DNA was used to assess the effects of ionizing radiation. In turn, the level of SSB DNA was determined by the value of the coefficient a DNA double helix unwinding in an alkaline environment. 


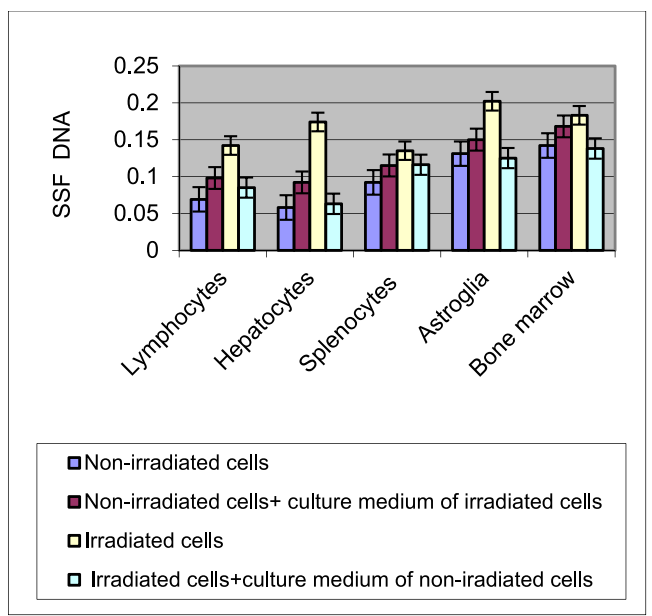

Fig. 21. Effect of living medium of exposed in vivo Balb/c mice cells to levels of SSB DNA at the first day after exposure to $\gamma$-fields with the accumulation of total external dose of about $5 \mathrm{~Sv}$.

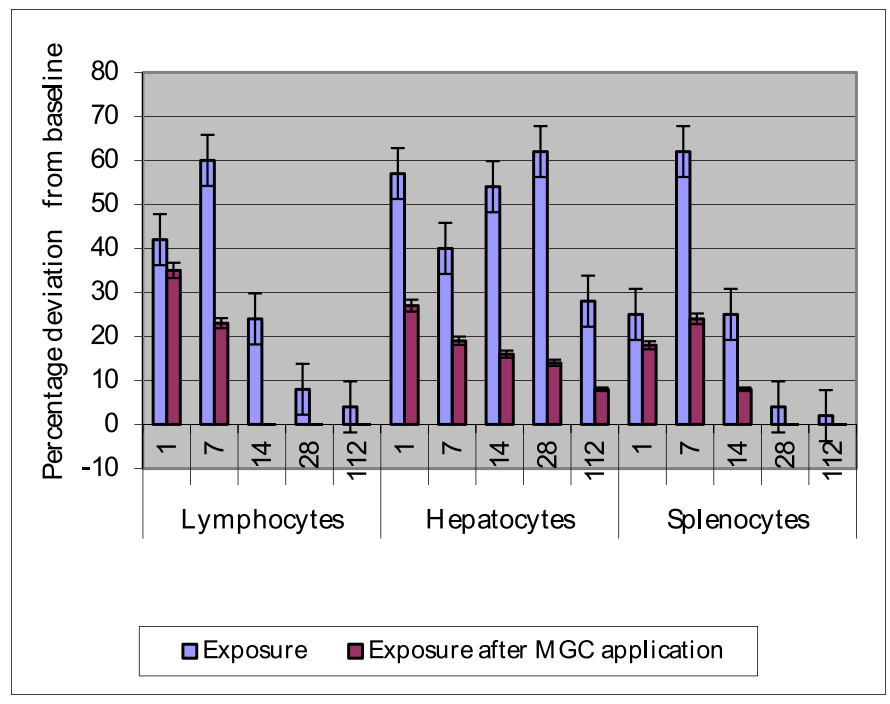

Fig. 22. Influence of living medium from cells irradiated mice and from cells irradiated mice that received intraperitoneal injection of MGC before exposure on the levels of SSB DNA at cells non-irradiated mice ( $1^{\text {st }}$ day after exposure at dose $5 \mathrm{~Sv}$

As we can be seen from Figure 21. data in all types of cells used in the first day after irradiation dose of $5 \mathrm{~Sv}$ significantly increases the level of SSB of DNA. At the same time it is shown that the living medium obtained after three hours stay of IrCs on the first day after exposure is able to induce an additional level of SSB DNA in different types of cells from not-irradiated mice $\mathrm{Balb} / \mathrm{c}$. In certain cases, the change of this indicator reaches significant differences, particularly 
in lymphocytes, hepatocytes and hematopoietic cells in bone marrow. While in splenocytes and astroglial cells revealed a clear trend towards increased levels of SSB DNA.

As shown in Figure 22 intraperitoneal injection of MGC, which has powerful antioxidant properties, into mice before irradiation procedure reduces the of BSE in all types of test cells and can serve as an argument in favor of the hypothesis about the important role of free radical molecules in the realization of this phenomenon. At the same time, it was shown that the transfer of "bystander" signals inside the irradiated Balb/c mice gradually decreases in all kinds of investigated cells during the first month after exposure and practically not detected 3,5 months after exposure (Figure 22). Receiving MGC before irradiation procedure is associated with a lower intensity "bystander" signaling in the period after exposure. The results of a comparative study of induction "bystander" signals in mice with different genetically determined radiation sensitivity under the same conditions of irradiation are shown in Figure 23.

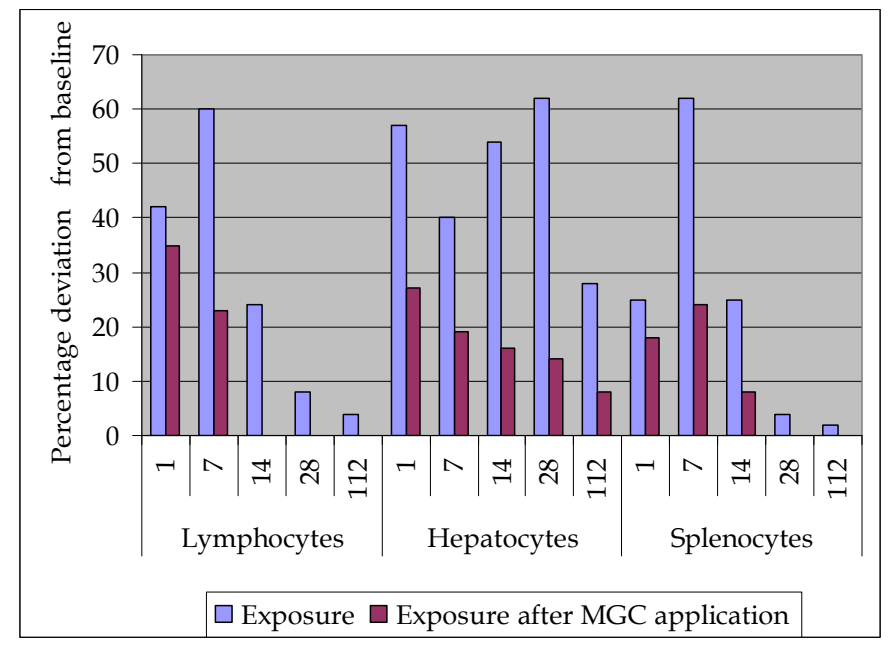

Fig. 23. Dynamics of development "bystander" effect for 112 days after MGC application before irradiation at a dose of $5.0 \mathrm{~Sv}$

At least in mice with lower level of $\operatorname{LD}_{50 / 30}($ Balb/c) induction of SSB in cellular DNA after exposure in living environment of the irradiated lymphocytes in various periods after of irradiation ranged from 150 to $200 \%$ when lymphocytes of mice more resistant to the effects of IR (C57Bl/ 6 with higher level of $\mathrm{LD}_{50 / 30}$ ) index of induction SSB in DNA of lymphocytes, respectively, was 2.5 and 5 times lower (Figure 24).

A correlation between higher index of $\mathrm{LD}_{50 / 30}$ and low induction as SSB DNA after irradiation, and induction of SSB DNA in modeling "bystander" effect in mice of C57Bl/6, can be explained by the presence in the cells of these animals melanized structures providing the black skin and fur. Antioxidants, photo- and radioprotective properties are a direct consequence of the free-radical structure of melanins, providing the opportunity to participate in electronic exchange of redox and radical processes. An attempt to identify "bystander" effect in vivo in mice of these lines under conditions of prolonged (over 231 
days) of exposure on concrete bars with radioactive soil, have accumulated a total dose of external irradiation on the level of $0.29 \mathrm{~Sv}$ also been made. The data are shown in Figure 25.

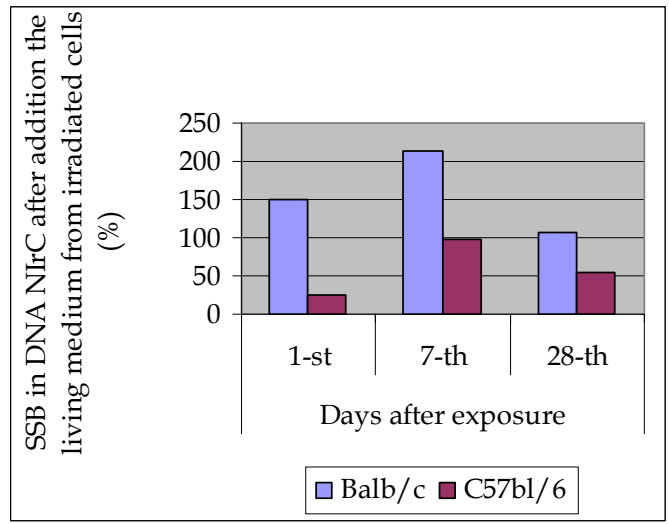

Fig. 24. Different influence of the living medium of $\operatorname{IrC}$ on NirC obtained from mice with differ in genetically determined level of sensitivity to IR.

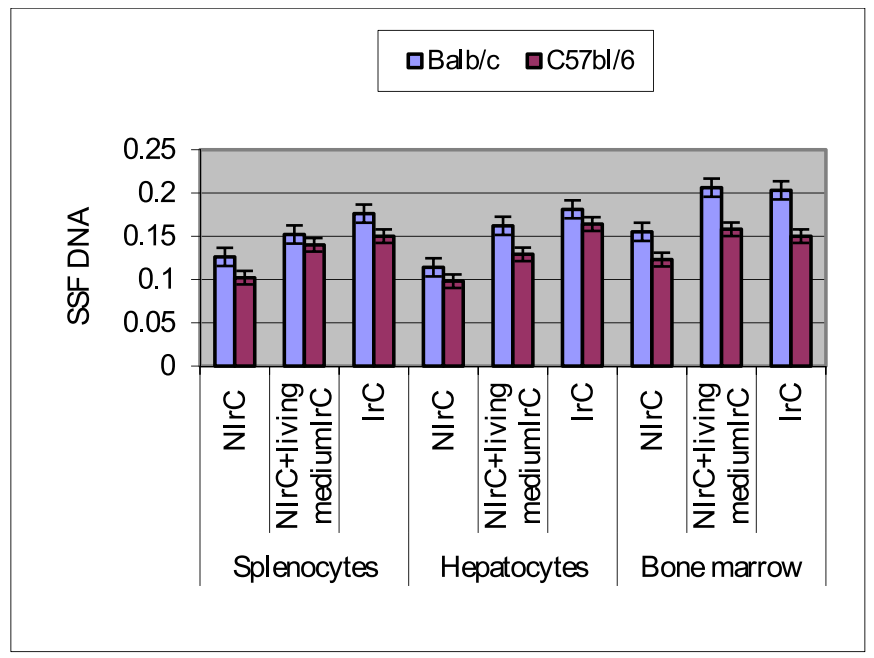

Fig. 25. Comparison levels of induction "bystander" signals in mice with different genetically determined radiation sensitivity under exposure during 231 day at dose $0.29 \mathrm{~Sv}$.

Analysis of the results of this study convinces us that prolonged exposure of linear mice under the effect of $\gamma$-fields of low intensity is associated with the induction of additional level of SSB in the DNA of cells of different origin. In this case, the phenomenon of amplification of radiological effects by means of "bystander" signals occurs. In this case, as with single-dose irradiation of $5.0 \mathrm{~Sv}$ "bystander" effect more clearly defined in biological mediums of mice with high sensitivity to the effects of ionizing radiation - line Balb/c. So, placing the NirC into living environment of the $\mathrm{IrC}$ Balb/c mice induces an increase in the level of SSB DNA in 
different cell types from 33 to $44 \%$, while a similar replacement of living medium in cells of mice $\mathrm{C} 57 \mathrm{Bl} / 6$ changes the indicated index in the lower range - from 27 to $32 \%$.

Detecting the ability of IrC to change the state of neighboring cells, through which not been laid tracks of ionizing particles, can in some extent explain the peculiarities of clinical realization of radiation effects at low doses of ionizing radiation. Identification BSE in liver tissue is an additional argument in favor of accepting the reality of the existence of diseases of hepato-biliary system of radiation origin. It was showed the development of the processes of autoimmune dysfunction in liver tissue during three-month exposure with accumulation total dose at $10.0 \mathrm{cSv}$ in model studies on linear mice Balb/c [Kovalev V., Krul N., Zhezhera V. 2010]. It is known that one of the responses the cell to irradiation is the destruction of the cells with the loss of a specific morphology and functional activity.

Nowadays are known several forms of death in cells that depend on the production of ATP apoptosis, necrosis and reproductive death. Postradiation apoptosis is characterized by maintaining the integrity of cell plasma membrane and the lack of contact, the intracellular content with cells of the immune system. In the end, remnants of apoptotic cells in tissues are removed by brushing up exfoliation in intraorganic space and subsequently excreted from the body. Mitochondria are the most sensitive to radiation cell organelles for several reasons: the practical absence of reparation and histone proteins that protect DNA, as well as the minimal activity of the enzymes to "cut out" and replace oxidized DNA regions [Anderson S, Bankier A.T. \& Barrell B.G. 1981, Berehovskaya N.N., Savich A.V. 1994]. In the cell inhibits the synthesis of ATP because degradation and loss of mitochondria. But at lack of ATP, in particular energy-dependent mechanisms of apoptosis may be switched off in connection with exposure to IR. In this case cell necrotizing with the loss of integrity of the cell membrane and release of macromolecular components (alanine aminotransferase (ALT), aspartate aminotransferase, etc.) in the intercellular space. Necrosis caused an immune response in the form of inflammation - leukocyte infiltration of damaged tissue, the accumulation of interstitial fluid with subsequent induction of specific immune response to unmasked and recognized by lymphocytes intracellular components. Thus, the cells from renewable tissues which are sensitive to IR (epithelium of the gastrointestinal and urogenital tract, respiratory tract), regularly die as a result of intense radiation exposure. Their contents are subsequently released in extracellular space and blood. Taking into account the above mentioned thoughts we additionally determined the levels of intracellular enzymes ALT levels in peripheral blood of different animal groups - the control and chronically exposed mice, and mice immunized with liver-specific lipoprotein (LSP). The preparation of liver-specific lipoprotein (LSP) has been isolated from the liver of syngeneic mice by the method described by McFarlane I.G. [McFarlane I.G., Wojicicka B.M., \& Zucker G.M., 1977]. It is a mixture of antigenic determinants of the substrate from the membranes of hepatocytes. Because of their lability, some proteins that are part of the LSP, in particular the asialoglycoprotein receptor [Treichel U., Schreiter T. \& Zumbuschenfelde K.H.M, 1995] under certain conditions, including under the influence of small doses of radiation may acquire properties of autoantigens.

The one group of mice was immunized LSP to confirm the immunogenicity of the resulting substance. The preparation of LSP has been isolated from the liver of syngeneic mice by the method described by McFarlane I.G. [McFarlane I.G., Wojicicka B.M. \& Zucker G.M. 1977]. The final concentration of protein in a preparation isolated by the method of Bradford [Bradford M.M. 1977] was $2.8 \mathrm{mg} / \mathrm{ml}$. The immunization scheme 
described in [Ryabenko D.V., Sidorik L.L., Sergienko O.V. 2001] was used. Increased serum level of this enzyme is considered a sign of inflammation in the liver - hepatitis, because a large amount of ALT released from the destructive cells of the body. Data obtained in this experiments are show in Figure 26.

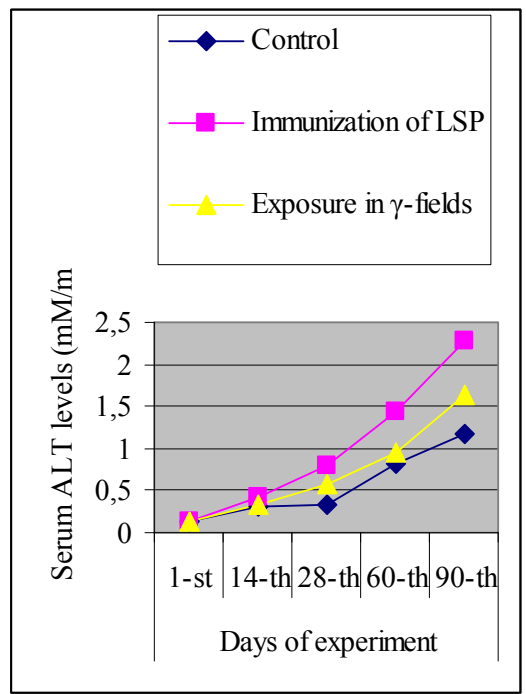

Fig. 26. Dynamics of serum levels of alanin aminotransferase in control, irradiated and immunized of LSP of mice Balb/c.

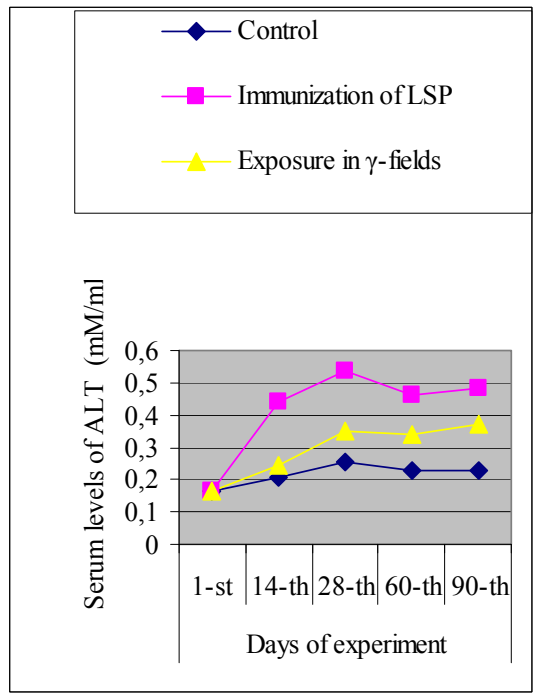

Fig. 27. Dynamics of serum levels of AuAB to LSP in control, irradiated and immunized of LSP of mice Balb/c. 
As shown by data presented in this Figures 26 and 27 a gradual increase in the concentration of ALT in the bloodstream is registered in all groups of animals observed. Increased serum levels of ALT in the mice of the control group reached significant difference in the fourth month of life and reflects a legitimate age-related changes of the liver associated with aging.

A clear tendency to increase this index in the group of animals treated with an immunogenic complex of proteins from the membranes of hepatocytes (LSP), when compared with that of control animals may be explained by stimulation of the processes of destruction of hepatocytes, mediated by immune mechanisms. More significant increase in the rate of ALT in blood is detected in irradiated mice (a significant increase in ALT is determined at the end of the first month of observation), and especially in mice immunized against membrane liver antigens contained in the LSP. Serum ALT levels increase in this group of experimental mice at the end of the second week after immunization began. Noteworthy the fact that the 100-day low-intensity radiation fields of fuel "hot particles" is quite effective in serum levels of ALT. Mice immunized with only one week ahead of irradiated mice to achieve a statistically significant increase of levels of this index compared with baseline. As follows from these data that a certain baseline level of AuAB to LSP is detected in the sera of control animals, and shows a tendency to increase during aging in mice. Amount of AuAB to LSP in immunized animals progressively increased and by the end of the first month of immunization reaches a peak and then decreases slightly and stabilizes over the next two months. In irradiated animals also determined by positive changes of serum levels of $\mathrm{AuAB}$ to LSP in the process of dose accumulation. In this group levels AuAB LSP to gradually increase and a tendency to increase $\mathrm{AuAB}$ remains at least during the observation period.

Registered positive changes of serum levels of ALT and of AuAB to LSP correlated with pathomorphological changes in liver tissue. In Figure 28. shows the morphological pattern of liver healthy 2-month old animal from the control group. Globular structure of the organ with well-differentiated trabeculae, which extend radially from the portal vein, clearly visible in the picture. The boundaries of cells and nuclei are well differ over the whole area of slice. In Figure 29 shown a slice of liver tissue with beginning an inflammatory process that is still impossible to differentiate as an autoimmune process. In figures 30 and 31 shown

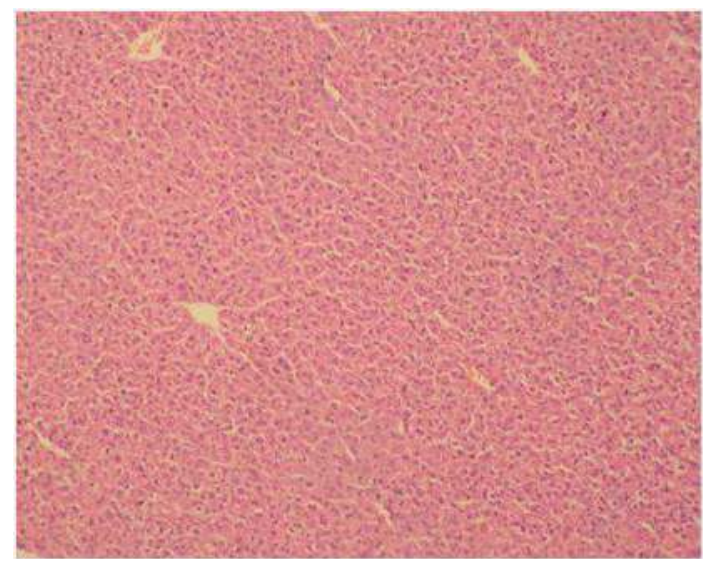

Fig. 28. Morphological picture of liver healthy 2-month old animal from the control group. 
deeper degenerative processes in the parenchyma with formation of lymphoid infiltrates. In a more favorable course of the process next sections of lesions appear regeneration areas. At high intensity the process changes in the tissues may be irreversible.

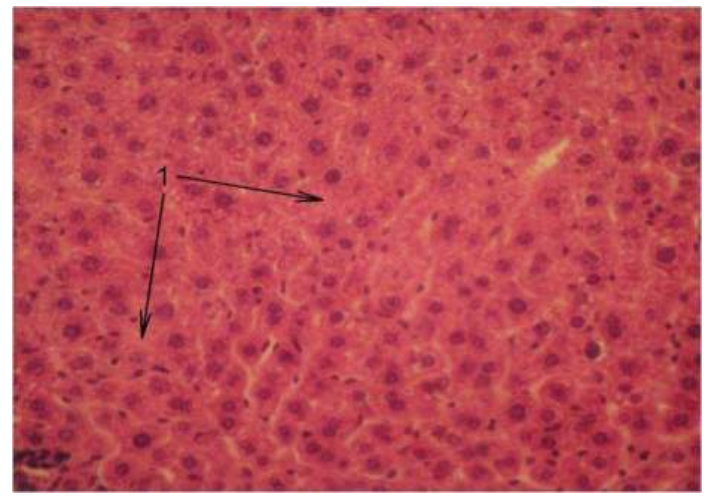

Fig. 29. Dystrophia of hepatocytes in violation of the architectonics of organ and the destruction of the nuclei. 1 - a violation of the architectonics of the lobules, blurred boundaries (irradiated mouse).

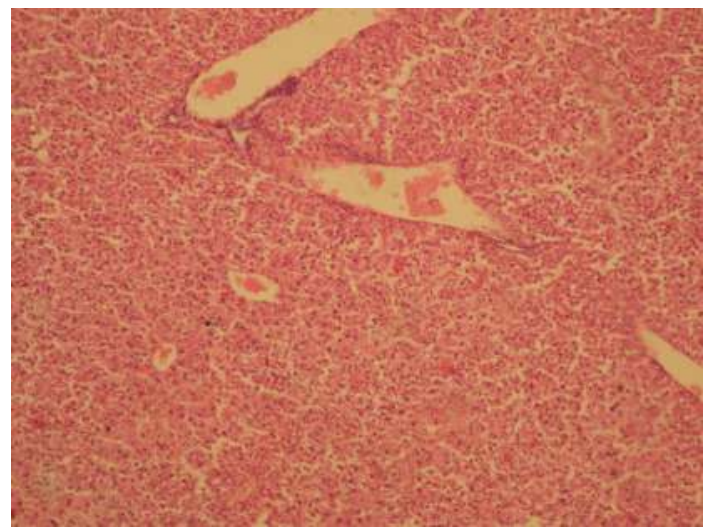

Fig. 30. Around blood vessels (or periportal) small clusters of mostly round the nuclear cell (lymphoid) elements. Stasis of blood within the vessel. More intensively painted the nucleus of cells (irradiated mouse).

Thus it was shown that exposure to IR can modify the immune status of the organism with the breakdown of immune tolerance and the subsequent emergence of autoimmune hepatitis. Its characteristic feature is the launch of autoimmune reactions against their own membrane antigens not only in the liver but also in other organs. The presence of long-term in excess of the background radiation pressure associated with the abolition of immune tolerance and the creation of conditions for the development of autoimmune reactions, in particular against antigens of liver tissue. As well known in turn the activity of autoimmunity is a favorable condition for the transfer of persistent infections in the active state and stimulation of vegetation as a saprophyte and pathogenic microorganisms was increased. 


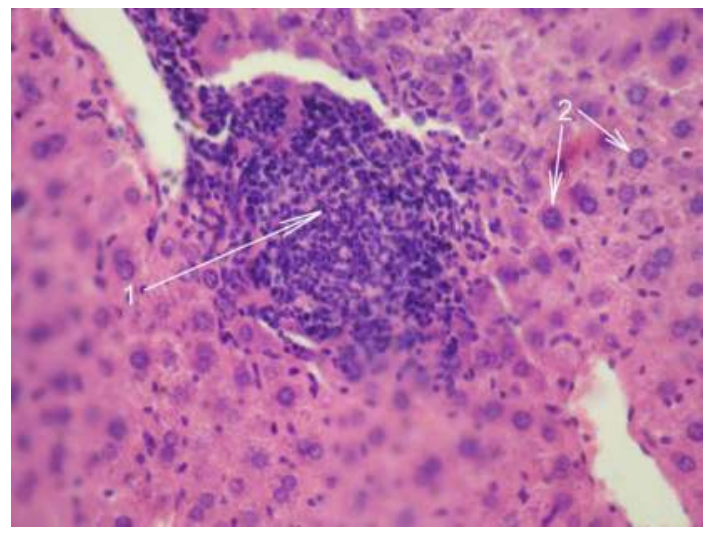

Fig. 31. Granulomas in the periportal areas of the parenchyma. 1 - Formation of granuloma on site infiltrate, 2 - Regeneration and repair of hepatocytes. (Irradiated mouse).

The impact of single external irradiation at a dose of $5.0 \mathrm{~Sv}$ for the transfer of intercellular signals in the bone marrow of mice Balb/c.

Nowadays it is known that hematopoietic stem cells (HSC) have higher radiation sensitivity than other cellular self-renewal systems. This conclusion was made by scientists on the basis of experimental works that showed the presence of the damage to hematopoietic progenitor cells not only due to the effects of the high doses but also upon action of the low doses of IR [Muksinova K.N., Mushkacheva G.S. 1995, Serkiz Ya.I. 1992].

It was shown that regeneration of the maturing cell pool and renewal of their quantity in the peripheral blood is determined by the completeness of the progenitor cell clone recovery. During the bone marrow regeneration period it was determined that both the proliferation of HSC is increased and the transition time of the maturing cell elements shortens [Bilko N.M. 1998, Bilko N.M., Klimenko S.V., Velichko E.A. 1999, Tavassoli M.V. 2008]. After acute period of the damage to the hematopoietic system regeneration phase follows, which is dependent on the viability of the stem cells, their migration ability in to the most affected areas of the hematopoietic tissues, time of proliferation and maturation of the committed progenitors and quantity of the functional mature cells [Shouse S.S., Warren A.S.L., Whipple G.H. 2004]. Critical for recovery of the hematopoiesis are quantity and quality of the HSC that recovered after irradiation. Possibility of hematopoiesis recovery is observed if more than $5 \%$ of the stem and progenitor cells remain intact and carry on proliferation and differentiation [Bond V.P., Fliedner T.M., Archambeau J.O. 2007]. If their level falls below this critical value, hematopoietic system can be exhausted due to lack of the stem cells capable of regeneration [Down J., Van Os. R., Ploemacher R. 1991]. Main proliferation stimulating factor of the HSC, which remain in the dormant state, is reduction of their quantity [Serkiz Ya.I., Pinchuk L.B. 1992]. Decisive role in the regulation of the recovery of the polipotent hematopoietic progenitors belongs to the microenvironment that upon interaction with HSC supports stability of their quantitative parameters in the physiological conditions and supports its recovery in case of injures [Hall E.J. 1991, Hall Mauch P., Constine L., Greenberger J. 2005]. Increase in the proliferation activity of the HSC is observed starting after irradiation exposure at the doses of 0.2 - 0.3 Gy [Grande T., Varas F., Bueren J.A. 2000]. 
The mechanism of the microenvironment influence on the hematopoietic system is still not fully determined. However, today it is known that its elements control the processes of hematopoiesis via production of the cytokines as well as by direct cell-to-cell contacts between HSC and microenvironment. Membrane-associated contacts serve for the transfer of the required molecules, homing and migration of the progenitor cells to the specific sites of the hematopoietic tissue and transport of the hematopoietic growth factors [Cronkite E.P., Inoue T., Hirabayashi Y. 2003]. Cultural investigations of the bone marrow (BM) indicated that despite the normalization of the quantitative parameters changes of the ability of hematopoietic elements to colony-forming had reduced character during prolonged periods of time with prevailing eosinophilic and neutrophilic colonies [Bilko N.M. 1998].

For the determination of the distant intercellular transfer of the post-radiation signals between the cells of irradiated animals a novel method of in vivo culture using diffusion capsules (DC) was described [Bilko N.M., Votyakova I.A., Vasylovska S.V., 2005]. Investigations were done of the Balb/c mice (Figure 32). The 16-hour model of exposure was used (see Protocol modes of mice irradiation). Animals were divided in to three groups: $1^{\text {st }}$ group was irradiated without the use of radioprotector, $2^{\text {nd }}$ group of animals received melanin - glucan complex prior to irradiation and the $3^{\text {rd }}$ group was non-irradiated control.
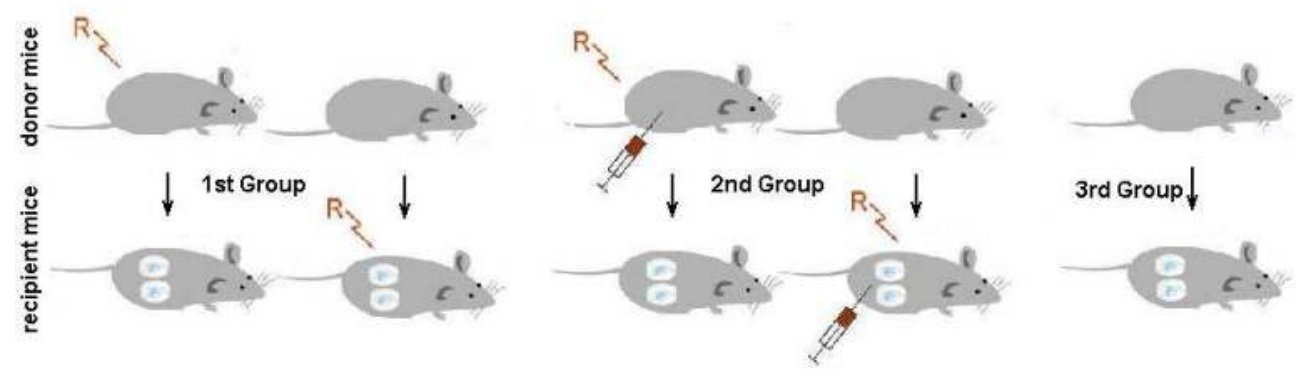

Fig. 32. Groups of experimental animals

Further each group was separated into the subgroups of the donors ( 3 animals) and recipients ( 3 animals for each donor and 2 capsules per recipient). Donor animals were sacrificed on the day 1 , day 7 , and day 30 after exposure and bone marrow cells were extracted from the femur. In each case, colony-forming activity $(\mathrm{CFU})$ in the culture was determined by injection of the $1 \times 10^{5}$ cells into the inner cavity of the diffusion capsule in the semisolid $(0.33 \%)$ agar Difco. Diffusion chambers (DC) permit free diffusion of the peptide factors; however, they allow avoiding any contact of the cultured material with the immune system of the recipient. Each animal was implanted with two DC into the peritoneal cavity under Sagatal narcotization. Animals were retained in the conventional vivarium conditions with 12-hour light/dark cycle illumination and free access to food and water. After 12 days implantation DC were extracted from the recipients and investigated under the inverted microscope for the CFU activity as indicated by formation of the colonies or clusters of the proliferated HSC.

The groups of cells less than 20 cells were considered as clusters, while groups of cells from 20-40 were considered as large clusters, and all cellular aggregates above 40 cells were counted as colonies (see Figure 33 and 34). 


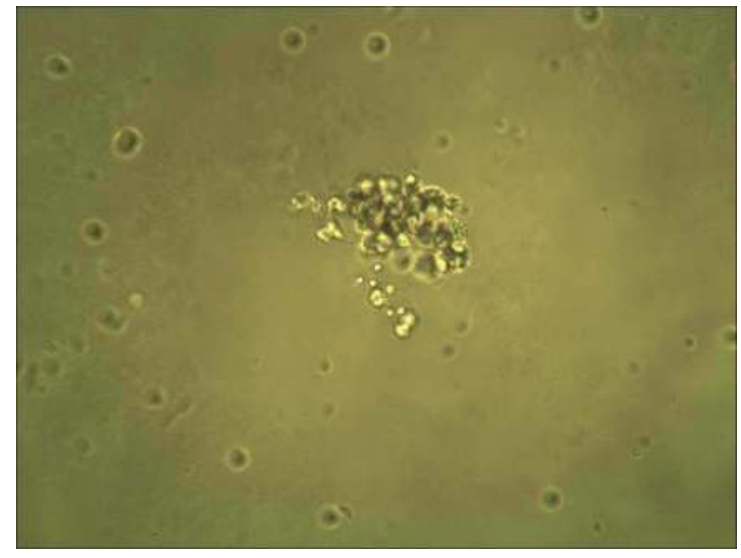

Fig. 33. Granulocyte-macrophage colony of mouse bone marrow culture of Balb/c, irradiated with a dose of 5.0 Sv. Inverted microscope, increase 200.

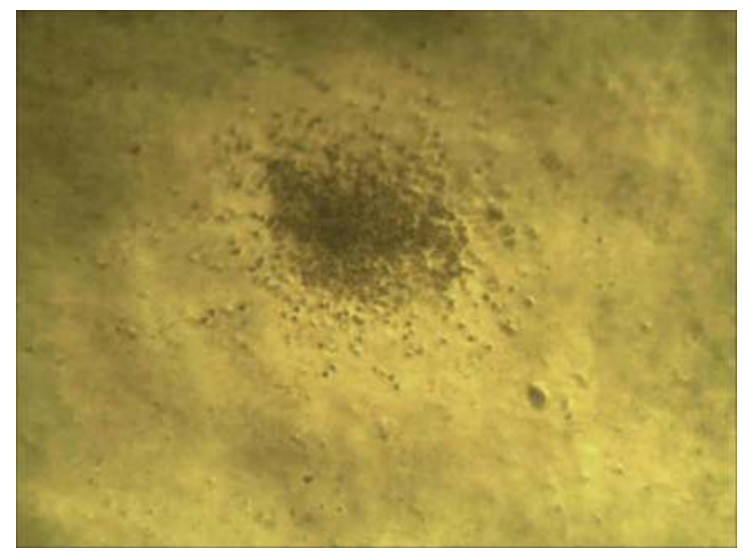

Fig. 34. Granulocyte cluster of mouse bone marrow culture of Balb/c, irradiated with a dose of $5.0 \mathrm{~Sv}$. Inverted microscope, increase 400 .

Cultured material was extracted from the inner cavity of the DC and individual colonies were picked up for the preparation of the cytospin slides and Pappenheim staining for identification of the cell types. Obtained data indicated that BM of the animals of the $1^{\text {st }}$ group was affected by the IR. Cell aggregate numbers were on average 24 colonies and 48 clusters in the cultures of the $1^{\text {st }}$ day after exposure. Almost no colony-forming activity was observed in the culture of $7^{\text {th }}$ and 30th day after exposure, that was indicative of significant suppression of the bone marrow function by the IR. At the same time in the culture of bone marrow cells that were obtained from the animals, which received MGC prior to exposure, the average colony count was 32 with 86 clusters at the $1^{\text {st }}$ day after exposure, 45 colonies and 112 clusters on the $7^{\text {th }}$ day after exposure, and 80 colonies and 136 clusters on the $30^{\text {th }}$ day after exposure.

These results may indicate that MGC is able to protect the population of the bone marrow stem cell population for the influence on the IR and stimulate recovery after irradiation at 
dose comparable to the $\mathrm{LD}_{50 / 30}$. This conclusion can also be supported by increase of the quantity of the CFU in comparison to the $1^{\text {st }}$ group of animals that have not received MGC. Implantation of the normal BM into the organism of the irradiated recipients at the $1^{\text {st }}$ day after exposure after culturing resulted in formation of 114 colonies and 386 clusters on average. In the cultures of the $7^{\text {th }}$ and $30^{\text {th }}$ days such proliferation activity was observed, that it was not possible to determine individual colonies or clusters. There is indicative of a significant stimulation of the release of the compensatory signal substances by the radioresistant stromal cells of the $\mathrm{BM}$, which highly stimulated the recovery of the radiationdamaged BM of the recipient. Normal bone marrow cells implanted into the irradiated mice treated with MGC yielded in 84 colonies and 192 clusters in the cultures of the $1^{\text {st }}$ day after exposure, 52 colonies and 548 clusters on the 7th day, and 106 colonies and 302 clusters in the $30^{\text {th }}$ day post exposure cultures (Figure 35).

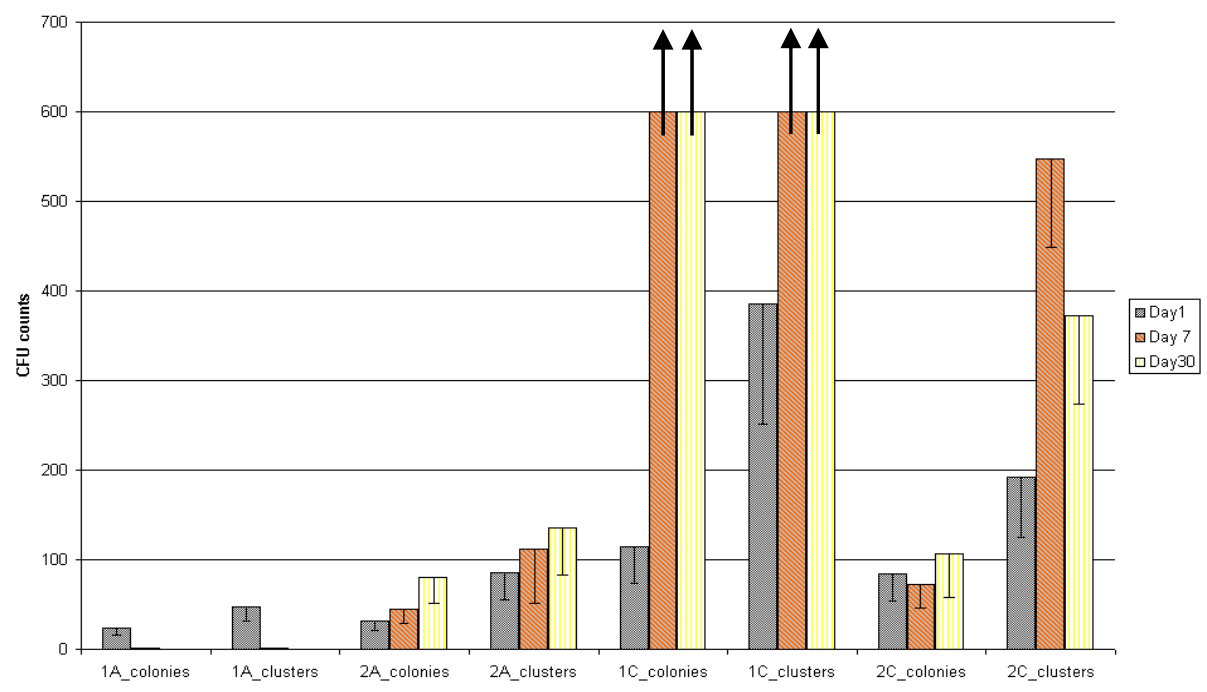

Fig. 35. Determination of the CFU activity of the bone marrow derived stem cells: Group 1A irradiated bone marrow culture in normal recipients; Group 2A - irradiated BM protected with MGC in normal recipients; Group 1C - normal bone marrow culture in irradiated recipients; Group 2C - normal bone marrow culture in irradiated recipients treated with MGC.

Such decrease in the CFU activity is indicative of less apparent stimulation of the compensatory factors release as a result of the radiation exposure due to protective effects of the MGC on the bone marrow cells so that less factors are required for reparation and therefore less factors are available for stimulation of the CFU activity in the DC.

Results of the in vivo culture of the bone marrow cells indicated that colony-forming activity of the hematopoietic progenitor cells of the animals non-treated with MGC prior to radiation exposure was significantly lower if compared to the control while treatment of the animals with MGC had increased the functional activity of the bone marrow cells.

Therefore upon irradiation exposure quantity of the hematopoietic stem cells is decreased and as a result, stromal component of the BM starts to secrete large quantities of cytokines 
and growth factors, which are able to stimulate HSC to active proliferation [Goldberg E.D., Dygai A.M. 2001]. Clearly, in animals irradiated at doses of $5.0 \mathrm{~Sv}$, production of growth factors was blocked by excessive amounts of free radicals which are formed when passing through biological tissue of ionizing particles [Timofeev-Resovskii N.V. 1963]. At the same time, free radicals can quickly neutralized by the MGC in mice receiving radioprotector. Improved products of growth factors caused the hyperproduction of bone marrow stem cells. On the $7^{\text {th }}$ day after exposure in the bone marrow culture of the irradiated animals, a deep depression in the CFU activity was observed. Finally pretreatment of animals with MGC resulted in the significant increase of the CFU activity. These data indicates that in the $\mathrm{BM}$ of irradiated animals the pool of later mononuclear cells was rapidly exhausted that resulted in the decrease of the CFU activity [Bilko N.M., Klimenko S.V., Velichko E.A. 1999]. In the group of animals pretreated with MGC prior to exposure, CFU activity in the BM increased during the experiment. On the 30th day post exposure, CFU activity of the bone marrow stem cells remained low and in the animals that have not received MGC, and in the animals treated with this radioprotector these values were significantly higher.

Obtained data may be indicative of the gradual recovery of the BM by implementation of the so called "golden reserve" of the stem cells that during radiation exposure were positioned in the crypts of the stroma and therefore remained undamaged [Tsyb A.F., Budagov R.S., Zamulaeva A.I. 2005]. Such significant effects of the MGC on the numbers of colonies and clusters in the DC cultures indicates decrease quantity of the stimulating bystander signals and strong radioprotective properties of the MGC, however the exact mechanism of action remains to be fully elucidated.

Concluding on the obtained experimental data it is clear that MGC is a strong radiation protector that helps to avoid consequences of the $\mathrm{LD}_{50 / 30}$ dose of irradiation at the level of HSC by affecting quantity of available growth stimulating factors that are commonly associated with radiation-induced damage to the BM.

\subsection{Influence radionuclide fallout to plant grown around object "Shelter" in Chernobyl alienation zone}

Contaminated of the wide territories in Ukraine not only with radionucludes ${ }^{137} \mathrm{Cs}$ and ${ }^{90} \mathrm{Sr}$, and with fission products of uranium and transuranium elements is an essential consequence of the accident at the IV block of Chernobyl Nuclear Power Plant that is classified as a global ecological catastrophe. The biota behaviors and adapt in this areas captured dose from radionuclide with long half-value period decay isotopes. As dose related amount of the isotopes ${ }^{137} \mathrm{Cs}$ and ${ }^{90} \mathrm{Sr}$ during long time after accident were decreased. But only the amount of the radioactive isotope ${ }^{241} \mathrm{Am}$ depend of time is increasing exactly in environmental alienation zone of Chernobyl. Radionuclide ${ }^{241} \mathrm{Am}$ as $\alpha$-emitter is a daughter product of ${ }^{241} \mathrm{Pu}$ isotope appeared after $\beta$-decay. The activity in environment of the isotope ${ }^{241} \mathrm{Am}$ is increasing with during time owing to $\beta$-decay of the ${ }^{241} \mathrm{Pu}$ isotope. The biota behavior in this areas captured dose from radionuclide with long half-value period decay isotopes. The peculiarity of radionuclides contamination associated with the Chernobyl accident is verified of physical and chemical forms of radioactivity elements through out into the environment [Rashydov N.M. 1999, Rashydov N.M., Konoplyova A.A., Grodzinsky D.M. 2004, Rashydov N.M., Kutsokon N.K. 2005, Rashydov N.M., Grodzinsky D., Berezhna V. 2006]. A part of the radioactivity isotopes is registered in water soluble droplets-liquid 
state, an other part - as "hot" particles, the interrelation between there forms being unstable and change under the influence of biotic and abiotic environmental factors. As rule in this conditions accumulation of radionuclides in plants which occurs mainly at the expense of their water-soluble and exchangeable forms, reflects rather complicated transitional processes in the soil, the rate and direction of these ones is determined by biological activity of all component of the plant rhizosphere inhabited layer of the soil. After Chernobyl accident already during 25 year a lot of "hot" particles transferred into fine dispersive conditions, which easy movements in outdoors where captured by biota which could characterize by help of transfer coefficient (TC) radionuclide ongoing. The transfer coefficient is ratio specific activities $(\mathrm{kBq} / \mathrm{kg})$ of plant to specific activity of soil $(\mathrm{kBq} / \mathrm{kg})$ where its grow that characterize go over a radionuclide from soil to vegetative plant on experimental plot. Necessary mentioned that the TC not constant and it differed on depend of parts of plant were determinate. For radionuclide ${ }^{241} \mathrm{Am}$ observed the value $\mathrm{TC}$ a lot of plants and mushrooms several order less than for isotopes ${ }^{137} \mathrm{Cs}$, $90 \mathrm{Sr}$. Especially for matured seed the value of the TC observed less than for other vegetative parts of the plant [Rashydov N., Berezhna V., Kutsokon N. 2007, Rashydov N.M., Kutsokon N.K. 2008, Rashydov N.M., Berezhna V.V., Grodzinsky D.M. 2009, Rashydov N., Berezhna V. 2010, Rashydov N.M. 2010, Rashydov N.M. 2011]. To study of the TC peculiarity modification is reason elucidation of our field research in alienation Chernobyl zone around object "Shelter".

Contamination of plant in natural experimental fields at the alienation zone of Chernobyl significant added by flying dust with very small size radioactivity particles less than "hot particles" in environment. The results received for plants soybean (content: ${ }^{137} \mathrm{Cs}-3.6$ $\mathrm{kBq} / \mathrm{kg}$ and ${ }^{90} \mathrm{Sr}-11.84 \mathrm{kBq} / \mathrm{kg}$ ) and flax (content: ${ }^{137} \mathrm{Cs}-0.78 \mathrm{kBq} / \mathrm{kg}$ and ${ }^{90} \mathrm{Sr}-3.55$ $\mathrm{kBq} / \mathrm{kg}$ ) which grown in Chistogalovka (specific activity of soil is $20.65 \mathrm{kBq} / \mathrm{kg}$ and 5.18 $\mathrm{kBq} / \mathrm{kg}$ for radionuclide ${ }^{137} \mathrm{Cs}$ and ${ }^{90} \mathrm{Sr}$, accordingly) and Chernobyl confirmed this hypothesis. The value TC for above mentioned seeds specimens collected from plant which grow on Chistogalovka was approximately 22.3 (soybean) and 6.63 (flax) times (for isotope ${ }^{137} \mathrm{Cs}$ ) and 13.97 and 4.71 (for isotope ${ }^{90} \mathrm{Sr}$ ) times higher by comparison with control variants which grown in Chernobyl where specific activity was $1.41 \mathrm{kBq} / \mathrm{kg}$ for radionuclide ${ }^{137} \mathrm{Cs}$ and $0.55 \mathrm{kBq} / \mathrm{kg}$ for isotope ${ }^{90 \mathrm{Sr}}$, correspondingly.

The peculiarity distribution in controlled laboratory conditions the radionuclide ${ }^{241} \mathrm{Am}$ in Arabidopsis thaliana plant on high level first layer leaves, in petiole and in carry out fascicles of the leaves significantly that go into this isotope from root system to top of plant very slow and membrane of cells played as discrimination barrier in this processes as mentioned in our previously investigations [Rashydov N.M., Berezhna V.V., Grodzinsky D.M. 2009].

In laboratory conditions for autoradiography investigation purpose the seedlings Arabidopsis thaliana were aseptically grown in hard agar cultured medium containing ${ }^{241} \mathrm{AmCl}_{3}$ in concentration with specific activity $50 \mathrm{kBq} / \mathrm{kg}$. After 25 days some leaves and top of stems of plants witch had not direct contact with medium were carefully cut off so that to avoid contact with medium. Selected parts of plants Arabidopsis thaliana settled down on the microscopic glass slides and dried a few days. During this process they were gluing to the slides themselves. The slides with parts of plants were coated with photo emulsion LM-1 in gel (Amersham - Biosciences UK) and exposure during time 20 days at temperature $+4^{0} \mathrm{C}$. After development the samples of slides were observed of the track of a-particles from radionuclide ${ }^{241} \mathrm{Am}$ with light microscope. A lot of datum confirmed that the coefficient 
uptake very small for radionuclide ${ }^{241} \mathrm{Am}$ and this element maldistribution by organs and tissues. We observed that accumulation the radionuclide of ${ }^{241} \mathrm{Am}$ depended of carry out fascicles system of the leaves and localization of the layer leaves not far from length root collar of plant which grow in laboratory conditions. The first layer leaves were taken up high-level amount radionuclide ${ }^{241} \mathrm{Am}$. As result the capture dose also may tissues of plant distribute no uniform. It is known that mineral nutrients are transported apoplastically, i.e. in the wall system outside the plasma membrane, or symplastically, i.e. in the cytoplasm from cell to cell deal with through plasmodesmata. The nutrient elements that penetrate into the cytoplast can also be shuttled into the vacuole via various mechanisms depending of biological function in cell life behaviors for mentioned isotope.

For field experiments we use plant white blow (Erophila verna (L.) Bess.) for autoradiography investigation from Chistogalovka and Yaniv contaminated soil sites the distribution radionuclide essential differs in spite of above-mentioned experiment. On the top shoot apex leaves and flower observed a lot of tracks of the particles $\alpha-$ and $\beta$-decays [Rashydov N.M., Berezhna V.V. 2010] (Figure 36).

Our experimental data confirms that radioactivity fallout in environment essentially differed important amendment of the TC. Thus extra-root nutrition that included micro- or nano- size "hot" particles had essential role of plant behavior in environment. But for plants that harvested from contaminated sites distribution of the radionuclide ${ }^{241} \mathrm{Am}$ by tissue and organs essentially differed from plants which grown in laboratory conditions.

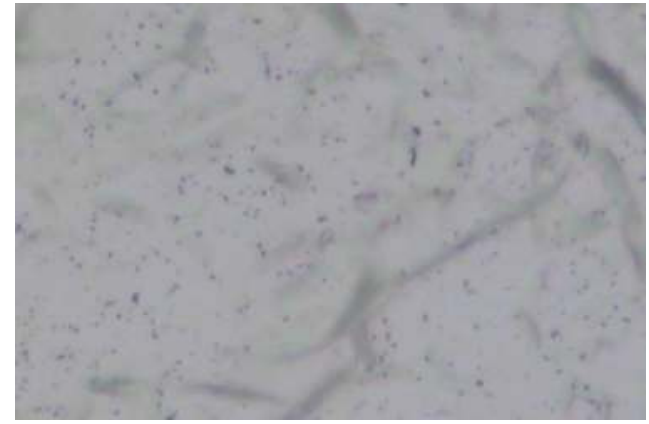

(a)

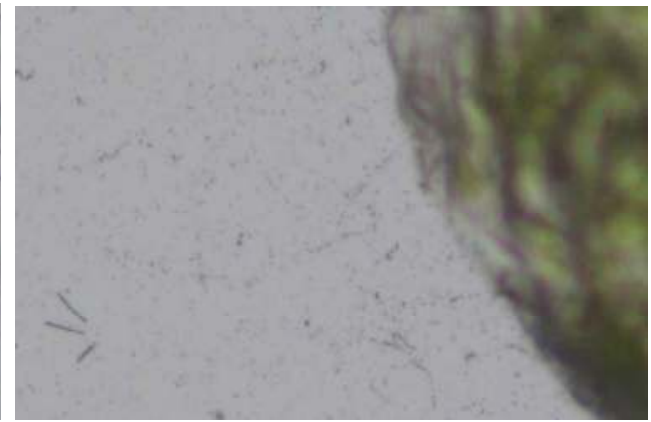

(b)

Fig. 36. Appear inside radioactivity of petal of bud (a) and also tracks of a-particles on surface of sepal (b) flower of the plants white blow (Erophila verna (L.) Bess.).

Contamination with radionuclide in natural experimental fields significant added tracks elementary particles from flying in air very small dust such as nano- and micro-size with radioactivity similarly "hot" particles in environment by help foliar pathway uptake into top leaves and aboveground apical apex of plants, especially around the object "Shelter".

\subsection{Flowering flax plant under chronic irradiation}

Flowering plant and seed development have long held the interest of general biologists because they represent a critical sensitivity changes phases in the pattern of shoot development and have significant consequences in creating yield seed [Hopkins W.G., 
Huner N.P.A., 2009]. The generative phase growth of plant include appear the floral organ with flower and filling seed event is involve important question: Why do plant this sensitivity processes controlled in shot during flowering spring and/or summer under stress factors? The flax plant flowering under chronic irradiation is a complex event that involves genome destabilizations as well as posttranslational regulation, signal transduction and epigenetic regulation metabolism inside living cell [Kutsokon N.K., Rashydov N.M., Grodzinsky D.M. 2007, Kutsokon N., Rashydov N.M. \& Grodzinsky D. 2003, Kutsokon N., Rashydov N.M. \& Berezhna V. 2004, Kutsokon N., Lazarenko L.M. \& Bezrukov V.F. 2004]. For shed light this problem we carry out especially experiment by help of pretreatment by melanin-glucan complex flax seeds which growth under chronic irradiation in Chernobyl zone. As well known the melanin-glucan complex has high gene protective response against of chronic IR in a wide range of doses due to capturing free radical regulation and influencing on epigenetic changes in cells. The curve bloom rate of flax plant depend of during of term observe and treatment by the melanin-glucan complex under influenced chronic irradiation shown in figure 37.

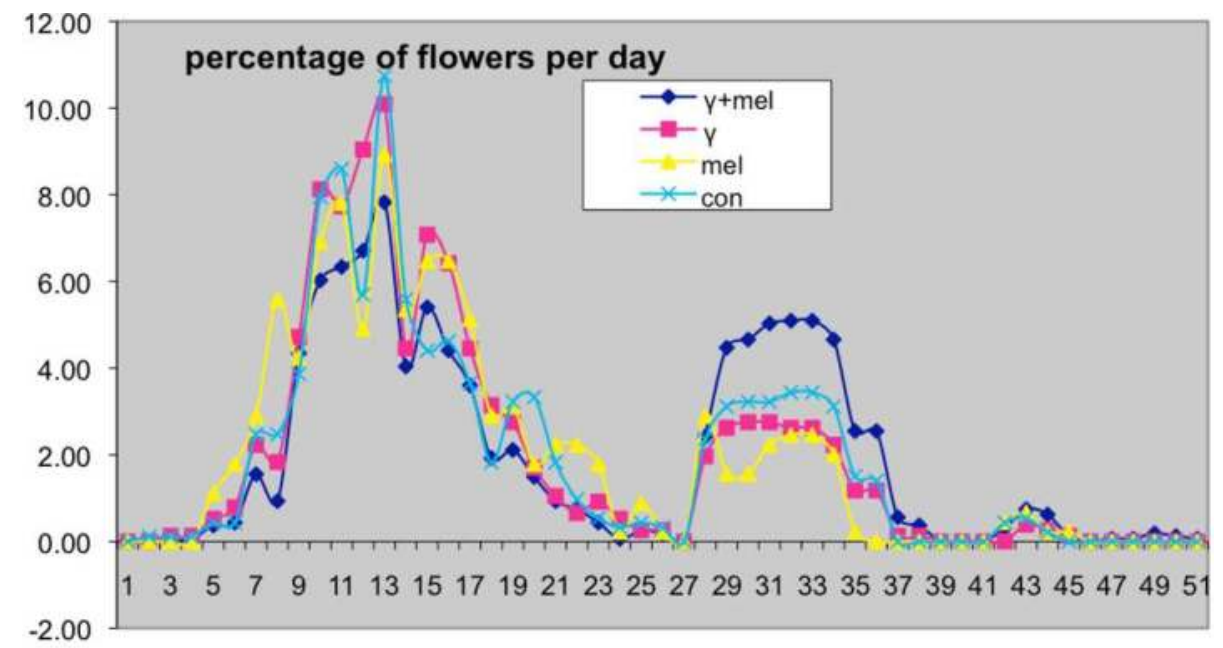

\section{time, days}

Fig. 37. Flowers per day depend of observed time and approach of treatment flax plants: with melanin-glucan complex plus chronic irradiation $(\gamma+$ mel $)$, irradiated by only chronic radiation $(\gamma)$, with melanin-glucan complex (mel) and control variant (con) without any treatments.

On base above given curves we were calculated for all variants for the experiment curve parameters that characterized the altitude rate bloom and the time of flower appear necessary for realization of the half of peak flowering. The height of the altitude curve of bloom $\mathrm{H}(\%)$ and half height of the peak flowering term $\mathrm{L}$ (days) of first and second bloom peak of flax plants which grown under different specific chronic irradiation with rate $2.6 \pm 0.3$ $\mathrm{mcSv} / \mathrm{h}$ and $25.4 \pm 0.4 \mathrm{mcSv} / \mathrm{h}$ to versus of control variants depend of melanin-glucan complex treatments shown at tables 1 and 2. 


\begin{tabular}{|c|c|c|c|c|c|c|}
\hline \multirow{2}{*}{ Variants } & \multicolumn{3}{|c|}{ First flowering peak } & \multicolumn{3}{c|}{ Second flowering peak } \\
\cline { 2 - 7 } & $\mathbf{H}, \%$ & $\mathbf{L}$, days & $\mathbf{R}^{2}$ & $\mathbf{H}, \%$ & $\mathbf{L}$, days & $\mathbf{R}^{2}$ \\
\hline $\begin{array}{c}\gamma+\text { melanin- } \\
\text { glucan complex }\end{array}$ & 7.2 & 14 & 0.91 & 3.3 & 15 & 0.96 \\
\hline$\gamma$ - irradiated & 9.4 & 12 & 0.95 & 2.1 & 11 & 0.96 \\
\hline $\begin{array}{c}\text { melanin-glucan } \\
\text { complex }\end{array}$ & 9.2 & 13 & 0.89 & 1.5 & 12 & 0.94 \\
\hline Control & 9.2 & 12 & 0.92 & 1.5 & 12 & 0.96 \\
\hline
\end{tabular}

Table 1. The altitude curve of bloom $\mathrm{H}(\%)$ and half height time L (days) of first and second flowering peak flax plants which grown under chronic irradiation with specific rate of radiation $2.6 \pm 0.3 \mathrm{mcSv} / \mathrm{h}$ and control variants depend of melanin-glucan complex treatments

\begin{tabular}{|c|c|c|c|c|c|c|}
\hline \multirow{2}{*}{ Variants } & \multicolumn{3}{|c|}{ First flowering peak } & \multicolumn{3}{c|}{ Second flowering peak } \\
\cline { 2 - 7 } & $\mathbf{H}, \%$ & $\mathbf{L}$, days & $\mathbf{R}^{2}$ & $\mathbf{H}, \%$ & $\mathbf{L}$, days & $\mathbf{R}^{2}$ \\
\hline $\begin{array}{c}\gamma+\text { melanin- } \\
\text { glucan complex }\end{array}$ & 6.6 & 9 & 0.91 & 5.5 & 8 & 0.96 \\
\hline$\gamma$ - irradiated & 8.4 & 10 & 0.89 & 3.0 & 8 & 0.96 \\
\hline $\begin{array}{c}\text { melanin-glucan } \\
\text { complex }\end{array}$ & 7.2 & 12 & 0.87 & 2.4 & 7 & 0.74 \\
\hline Control & 7.6 & 10 & 0.92 & 3.7 & 8 & 0.94 \\
\hline
\end{tabular}

Table 2. The altitude curve of bloom $\mathrm{H}$ (\%) and half height time L (days) of first and second flowering peak flax plant which grown under chronic irradiation with specific rate of radiation $25.4 \pm 0.4 \mathrm{mcSv} / \mathrm{h}$ and control variants depend of melanin-glucan complex treatments

As shown from figure 37 after 10-15 days since started flowering period the percent of flax flower per day increased until maximal magnitude and the curve passed first peak. During 10-12 day bloom probable decrease until zero and keeping in spontaneous level a few days. But after that during 10-12 days probable of bloom increased and on the curve appear second late flowering peak. For treatment melanin-glucan complex reveal more quantity flower release during second bloom period depend of chronic irradiation: yield proximally $3.3 \%$ under chronic irradiation with specific dose $2.6 \mathrm{mcSv} / \mathrm{h}$, in case specific dose 25.4 $\mathrm{mcSv} / \mathrm{h}$ it increased until 5.5\%, accordingly. Increasing the second peak inflorescence appear for both curves variant treatment with melanin-glucan complex at dose $2.6 \mathrm{mcSv} / \mathrm{h}$ as well as under chronic irradiation specific dose $25.4 \mathrm{mcSv} / \mathrm{h}$ deal with involve this subtract in epigenetic changes in genome regulations flowering process during ontogenesis of flax plants. Necessary mentioned that the bloom of second peak for several plant usually 
excited appear sterility flowers but for flax was appeared yield in second peak bloom a lot of fertile seeds in generally with germination rate proximally $97 \%$. However the average numbers of seeds per seed box or per infructescence of plant flax grown in several conditions do not differed from control variant significantly.

As known epigenetic events regulate the activities of gene which take part in vegetative and generative phases of growth plant by help of processes methylation of DNA, acetylation, phosphorylation of the histone tails in chromatin fiber. The heritability of DNA methylation, which often occurs in the early and late stages of vegetative development of the ontogenesis plant, allows cells to keep irrelevant genes silenced in successive generations of embryo cell. However some genes - such as plant genes that govern cell dormancy and spring time flowering - require silenced genes to be reactivated. Evidence is beginning to emerge those different classes by help of micro ribonucleic acid (miRNA) and on noncoding RNAs regulate these protein synthesis [Danchenko, M., Škultéty, L. \& Berezhna, V.V. 2008, Danchenko M, Skultety L. \& Rashydov N.M. 2009, Danchenko M, Klubicova K. \& Skultety L. 2011]. Thus the seedlings since germination until flowering, filling seed and matured seed during all ontogenesis term under chronic irradiation perceived some signal transduction events which accumulate permanently in plants as epigenetic changes transient heritability.

\section{Conclusion}

Quality and qualitative changes in the structure of the radiation factor of object "Shelter" occurred over twenty-five years of its existence. Inside the "Shelter" the spontaneous destruction of the fuel-containing materials in IV Unit of the ChNPP which arose out of nuclear fuel in the acute phase of the disaster under the influence of intense ionizing radiation and high temperatures was developing. As a result of a new type of radioactive aerosol particles of nanometer size were appeared as called fuel hot particles. Accumulation of radionuclides with long half-life, in particular, radioactivity isotopes of strontium and plutonium and their decay products in the tissues of plant and animal organisms is especially dangerous. The fuel-containing materials are dissolved under the action of microorganisms and a new compound of radioactivity isotopes with organic matter was appeared. They are potentially more mobile and more ecologically dangerous around and inside "Shelter" environments. The radiation fields with different intensity inside object "Shelter" have contributed to increasing the mutation rate and breeding of radiationresistant microorganisms with new aggressive properties. A lot of number particles of micrometer and nanometer size which consisting the cells of microorganisms and spores in the investigated samples of aerosols originated from "Shelter" premises. It is known that the light roof of sarcophagus has a large number of defects and some of these microorganisms, especially in the form of spores, may potentially carry away outside of the object "Shelter".

The hot particles of fuel contain gamma-, beta- and alpha- irradiators, such as radioisotopes of strontium and plutonium and their decay products continue irradiating organism late times even after termination of introduce to them. When IR from similarly radioactivity isotopes interaction with living matter they pass it relatively high energy. It is being spent on the excitation of atoms or ions and changes the chemical properties of matter and additional radicals may be appeared in living cells. 
As rule the linear non-threshold concept suggests that DNA damage induced by low doses of radiation do not contribute significantly to increased risk of disease because a significant amount of endogenous genome damage occurs and is restored in cells constantly. The main difference between DNA damage induced by IR, from the endogenous damaged - it's clustering and the complexity of their chemical nature. The proportion of complex, critical for the fate of the cell damage is much higher when exposed to chronic IR. Especially the massive clustering of DNA damage occurs when the ionization tracks pass along chromatin fiber. At the same time it is known that the probability of occurrence of endogenous clustered DNA damage is extremely low. Accumulation a lot of endogenous damages does not occur because in the cells are constantly functioning mechanisms of reparation, specifically targeted at removing various types damages. Low doses of IR can not activate the $\mathrm{G}_{2} / \mathrm{M}$ chekpoynt-arrest and DNA repair are not activated when the number of DSB DNA damage and crosslinks between the fibers under 10 - 20 per cell.

There are four outcomes for the cell fate, if the cellular radiation damage is not adequately was repaired. The cell may die or will delay it or keep playing with the viability of new qualities or mutations as the basis for the development of remote descendants.

The energy dependence of the mechanisms of apoptosis is disabled after irradiation, and the cell dies with loss of cell membrane integrity and its release of macromolecular components, such as intracellular enzymes etc., into the intercellular space. These substances cause an immune response in the form of inflammation as leukocyte infiltration of the affected tissue, interstitial fluid accumulation and subsequent induction of specific immune responses (specifically sensible T-lymphocyte and autoantibody) to the unmasked and recognized by lymphocytes of intracellular components.

We detected a significant increase in the rate of ALT levels in chronically irradiated by low doses mice Balb/c compared with non-irradiated. Increased serum levels of this enzyme are considered a sign of inflammation in the liver because a large amount of ALT is released from the damaged cells of this body. Positive changes of serum levels of AuAB to liverspecific protein (LSP) that is a mixture of antigenic determinants of the substrate from the membranes of hepatocytes are also determined in the process of dose accumulation at irradiated animals. Because of their labiality, some proteins that are part of the LSP in particular the asialoglycoprotein receptor under certain conditions including under the influence of small doses of radiation may acquire properties of auto antigens.

Thus chronic exposure to low doses of ionizing radiation of low intensity may lead to the abolition of immune tolerance, not only in the liver but also in other organs. As is known in turn increased the activity of autoimmunity is a favorable condition for the transfer of persistent infections in the active state and for stimulation of vegetation as saprophyte and pathogenic microorganisms.

It is known that the IR increases the level of signal transduction in the infected cell and can activate the promoter of certain genes of the virus and subsequent synthesis of the corresponding proteins. As a result of these events, the cell does not die, as is the case with an active infection, and changes its functional properties. In this changing antigenic repertoire of cell membranes was described. Antigens become available for immune recognition. As a result by an autoimmune reaction and changes the pathogenesis of a wide range of infectious diseases to cancer stimulated. 
The main outcome of the 25-year study of morbidity in different categories of exposed persons in connection with the Chernobyl catastrophe is a significant increase in primary morbidity is not associated with tumor pathology. An additional mechanism of radiobiological effects in mammals, which can have a direct influence on the biomedical effects of radiation, was described. This is a phenomenon of production by irradiated cells of signals that cause lesions similar to radiation damage in no irradiated neighbor cells as "bystander effect" (BSE) was named. We used index of SSB DNA as indicator to assess the effects of ionizing radiation. It was shown that the living medium obtained after three hours stay of IrCs on the first day after exposure at dose $5.0 \mathrm{~Sv}$ for 16 hour is able to induce an additional level of SSB DNA in different types of cells from not-irradiated mice Balb/c - in lymphocytes, hepatocytes, bone marrow hematopoietic cells, splenocytes and astroglial cells. Identification BSE in liver tissue is an additional argument in favor of accepting the reality of the existence of diseases of hepato-biliary system of radiation origin.

At the same time it was shown that the transmission "bystander" signals within the irradiated BALB/c mice were observed for at least one month after exposure. We also found a correlation between high rate of $\mathrm{LD}_{50 / 30}$ and low induction SSB DNA in non-irradiated cells after placing them in the living environment of cells from irradiated animals. In mice with lower level of $\mathrm{LD}_{50 / 30}(\mathrm{Balb} / \mathrm{c})$ induction of SSB in cellular DNA non-irradiated lymphocytes after exposure in living environment of the irradiated cells in various periods after of irradiation was higher in comparison with similar index of C57Bl/6 mice with higher level of $\mathrm{LD}_{50 / 30}$. We observed BSF in mice of two lines with different modes and doses: the external influence of gamma-ray dose, $5.0 \mathrm{~Sv}$ (for 16 hours), and external chronic exposure for 231 days with a cumulative dose of $0.29 \mathrm{~Sv}$, with internal radiation for 74 days with the accumulation of activity in the mouse body about $18 \mathrm{kBq}$.

The reactive oxygen species (ROS) play an important role in the mechanisms of signal transmission to "bystander" cells. Reinforced ROS production in non-irradiated cells incubated in medium from serum, irradiated gamma-particles, or from supernatant of the suspension of irradiated cells was shown by many authors. Irradiated cells produce a spectrum of "bystander" signals - cytokines, fragments of DNA (from apoptotic cells) or other factors of protein nature. These factors cause a change in oxidative metabolism and gene expression profiles in irradiated cells, and induce enhanced production of highly reactive oxygen species. In addition to chemical modification of DNA nucleotides, the formation of radicals can also lead to changes in the higher levels of organization structure of the molecule - the secondary, tertiary and quaternary.

Therefore the melanin-glucan complex (MGC) from higher mushroom basidiomycetes Fomes fomentarius, was used as an antioxidant to confirm the involvement of molecules of free-radical nature to the transmission of signals from irradiated cells to non-irradiated cells after external influence of gamma-rays (the model of the single and chronic exposure of mice). Antioxidants, photo-and radio-protective properties are a direct consequence of the free-radical structure of melanin providing the opportunity to participate in electronic exchange of redox in cell and radical recombination processes around DNA damages. We have shown that intra peritoneal injection of MGC, which has powerful antioxidant properties, to mice prior to irradiation at a dose procedure 5.0 Sv decreases from BSE in all kinds of testing cells and increase the number of colony forming units in bone marrow 
of irradiated mice. These results may serve as an argument in favor of the hypothesis about the important role of free radicals, molecules in the implementation of the phenomenon of BSE. Concluding on the obtained experimental data it is clear that melanin-glucan complex is a strong radiation protector that helps to avoid consequences of the $\mathrm{LD}_{50 / 30}$ dose of irradiation at the level of HSC by affecting quantity of available growth stimulating factors that are commonly associated with radiation-induced damage to the bone marrow.

In the experiments on vegetative plant test-system evidence that under influence chronic irradiation were formed radiobiological reactions living organisms which include several level functions and structure organization processes since metabolic pathways and cellular systems until genetically and population changes. We observed that accumulation the radionuclide of ${ }^{241} \mathrm{Am}$ depended of carry out fascicles system of the leaves and localization of the layer leaves not far from length root collar of plant which grow in laboratory conditions. The first layer leaves were taken up high-level amount radionuclide ${ }^{241} \mathrm{Am}$. The peculiarity distribution radionuclide ${ }^{241} \mathrm{Am}$ in Arabidopsis thaliana plant on high level layer leaves, in petiole and in carry out fascicles of the leaves significant that go into this radioactivity isotope from root system to top of plant very slow and membrane of cells played as discrimination barrier in this processes as mentioned in our previously investigations. It is known that mineral nutrients are transported apoplastically, i.e. in the wall system outside the plasma membrane, or symplastically, i.e. in the cell wall system outside the plasma membrane, or symplastically, i.e. in the cytoplasm from cell to cell deal with through plasmodesmata. Elements that penetrate into the cytoplast can also be shuttled into the vacuole via various mechanisms depending of element. But for plants that harvested from contaminated sites distribution of the radionuclide ${ }^{241} \mathrm{Am}$ by tissue and organs essentially differed from plants which grown in laboratory conditions. When we observed plant white blow (Erophila verna (L.) Bess.) for autoradiography investigation from Chistogalovka and Yaniv contaminated soil sites the distribution tracks of radionuclide essential differ in compare of above mentioned experiment. Contamination with radionuclide in natural experimental fields significant added tracks elementary particles from flying in air very small dust such as nano- and micro-size with radioactivity less than "hot" particles in environment by help foliar pathway into top leaves and apex of plant. Existence of nano- and micro- size dust as radioactive aerosols with specific properties around object "Shelter" circulate an environment represents potential risk radiobiological consequences of plant that grow in alienation Chernobyl 30-km zone.

The chronic irradiation around object "Shelter" was including instability genome, which carried out genetic and somatic changers in late heritable on perennials as well as in several generation annual plants. Proteomics analysis observes; bloom, filling and maturing seeds evidence that there is induce epigenetic changes of genome that excited late genetic changers on progenies and somatic changes of flax plant. Treatment by the melanin-glucan complex from fungus $F$. fomentarius before sowing seed procedure increase second peak on flowering curve depend of ontogenesis flax under influence chronic irradiation.

It is known that under chronic irradiation the epigenetic events regulate the activities or inactivate of genes by help of several mechanisms which may be include miPNA inter action deal with process that take part in vegetative and generative phases (bloom, filling and maturing seed) of growth plant by help of processes methylation of DNA, acetylation, 
phosphorylation of the histone tails in chromatin fiber of chromosome. However some genes - such as plant genes that govern cell dormancy and spring time flowering - require silenced genes to be reactivated. The heritability of DNA methylation, which often occurs in the early and late stages of vegetative development of the ontogenesis plant, allows cells to keep irrelevant genes silenced in successive generations of embryo cell. Evidence is beginning to emerge those different classes by help of micro ribonucleic acid (miRNA) and on noncoding RNAs regulate these protein synthesis.

Our experiments carry out with chronic irradiation revealed that in mammalian and plants cells excided not only direct damage DNA or appear mutation event as well as were observed complex responsible processes including genome instability, signal transduction, bystander effect between sells and epigenetic changes several profiles protein synthesis depend of activity or silent some genes which adjusted by help of treatment melanin-glucan complex.

\section{Acknowledgment}

The authors thanks to deputy director of the Nuclear Research Institute of National Academy of Sciences of Ukraine Dr. Tryshyn V.V. help us with maintenance radioactivity measure of several contaminated samples by radionuclides from Chernobyl zone.

\section{Keywords}

Chernobyl, object "Shelter", radioactive isotopes, "hot" particles with micro- and nano-sizes, radioactivity aerosol, embryogenesis, signal system, autoradiography, single strand break (SSB) DNA, chronic irradiation, bystander effect, autoimmunity, alanine aminotransferase (ALT), liver-specific lipoprotein (LSP), radiation hepatitis, bone marrow, hematopoietic stem cells, medical consequence, melanin-glucan complex, flowering of flax, epigenetic.

\section{References}

Anderson S, Bankier A.T., Barrell B.G., de Bruijn M.H., Coulson A.R., Drouin J, Eperon I.C., Nierlich D.P., Roe B.A., Sanger F, Schreier P.H., Smith A.J., Staden R, Young I.G. Sequence and organization of the human mitochondrial genome// Nature. 1981 Apr 9; 290(5806): p.457-65.

Ashmarin I.P., Freidlin V.P. History and the practical aspects of a new understanding of the role of autoimmunity. Abstracts 1st Moscow International Conference "Natural autoimmunity in health and disease. " Moscow. 15 - 17 September, 2005, 245p.

Azzam E.I., Little J.B. The Radiation-induced Bystander effect: Evidence and Significance. In: Bystander effects and the dose response. Belle News-letter/ Biological Effects of Low level Exposure. 2003. V.11.N 3 P .2 - 6.

Azzam, E.I., de Toldeo, S.M., Little, J.B. Stress signaling from irradiated to non-irradiated cells/ / Current Cancer Drug Targets. 2004. Vol.4 N 1. P. 53-64.

Ballot E., Homberg J. C., Johanet C. Antibodies to soluble liver antigen: an additional marker in type 1 auto-immune hepatitis / / J. Hepatology, - 2000. - 33, - P. 208 215. 
Baryakhtar V.G., Gonchar V.V., Zhidkov A.V., Klutchnikov A.A. Dust productivity of damaged irradiated fuel and lava-like fuel-containing materials of "Shelter" object. Preprint of ISTC "Shelter" of Natl. Acad. Sci. of Ukraine, 1997, No.97-10, p.197 (in Russian).

Baryakhtar V., V.Gonchar, A.Zhidkov, V.Zhydkov Radiation damages and self-sputtering of high-radioactive dielectrics: spontaneous emission of submicronic dust particles // Condensed Matter Physics, 2002, Vol.5, No.3(31), p.449-471.

Baverstock K. Radiation-induced genomic instability: a paradigm-breaking phenomenon and its relevance to environmentally induced cancer // Mutat. Res. 2000. V.454. No 1-2. P.89-109.

Bennett P.V., Cintron N.S., Gros L., Laval L. And Sutherland B.M. Are endogenous clustered DNA damage induced in human cells? // Free Radic. Biol. Med. 2004. V. 37. P.488-499.

Berehovskaya N.N., Savich A.V. Radiation damage of mitochondrial genome and its role in long-term consequences of irradiation // Radiat. Biol. Radioekol. 1994. V 34. No 3 P.349-351.

Bilko N.M., Klimenko S.V., Velichko E.A., Zhazhal E..I Peculiarities of hemopoiesis in reconvalescents of acute radiation sickness in a period of long-term effects / Proceedings of scientific papers KIAPE. - Kiev, 1999. - Issue8. - P.40-43.

Bilko N.M. Hemopoietic progenitor cells in radiation exposure (an experimental and clinic study): Author. dis. Dr. med. Sciences: 03.00.01 / NAS, Inst Exp. pathologies., oncology. i radiobiol. - K., 1998. - 31 p.

Bilko N.M., Votyakova I.A., Vasylovska S.V., Bilko DI.Characterization of the interactions between stromal and haematopoietic progenitor cells in expansion cell culture models. / Cell Biol Int. 2005 Jan; 29(1): p. 83-86.

Blandova Z.K., Dushkin V.A., Malashenko A.N. Lines of laboratory animals for biomedical research / M. "Science." 1983. 180 p.

Bond V.P., Fliedner T.M., Archambeau J.O. Mammalian Radiation Lethality. // New York: Academic Press. - 2007. - 159 p.

Bondarenko O.A., Aryasov P.B., Melnichuk D.V., Medvedev S.Y. Analysis of aerosol distribution inside the object "Shelter" at the Chornobyl reactor site // Health Physics, 2001, vol.81, No.2, p.114-123.

Bont R.D., Van Larebeke N. Endogenous DNA damage in humans: a review of quantitative data. Mutagenesis. 2004. V19. P. 169-185.

Bouzounov O.V., Tereshchenko V.M. Mortality from non-neoplastic diseases of participants aftermath of the Chornobyl nuclear power plant in a post-accident period, doze dependent effects. In the book. Problems of radiation medicine and radiobiology. Proceeding of scientific papers. Ed Bebeshko V.G. Issue 15., Kiev, 2010. p. 416.

Bradford M.M. A rapid and sensitive method for quantitation and microgramm quantities of protein utilizing the principle of protein binding / / Anal.Biochem. - 1977 - 1986. - P. 193-200.

Bradley M.O., Kohn K.W. Fluid mechanisms of DNA double-strand filter elution / / Nucleic Acid Res. 1979. Oct 10, 7 (3). P.793-804. 
Brenner D.J., Doll R., Goodhead D.T., Hall EJ, Land CE, Little JB, Lubin JH. Cancer risk attributable to low dose of ionizing radiation: assessing what we really know // Proc. Natl. Acad. Sci. USA. 2003. - V. 100.-P. 13761-13766.

C. Garcia-Buey L., Garcia-Monzon C., Rodriguez S., Bourque M.J., Garcia-Sancherz A., Iglesias R., De Castro M., Mateos F.G., Vicario J.L, Baslos A. Latent autoimmune hepatitis triggered during interferon therapy in patients with chronic hepatitis C / / Gastroenterology -1995. - №.108. (6) -P. 1770-1771.

Chakraborty A, Held K.D., Prise K.M., Liber H.L., Redmond R.W. Bystander effects induced by diffusing mediators after photodynamic stress// Radiation Research, 2009. V.172. N.1. P. 74-81.

Churilov L.P. Autoimmune regulation of cellular functions, human antigenome and autoimmunomic: a paradigm shift // Medicine twenty-first century. 2008, 4 (13). p. $10-20$.

Cronkite E.P., Inoue T., Hirabayashi Y., Bullis J. Are stem cells exposed to ionizing radiation in vivo as effective as nonirradiated transfused stem cells in restoring hematopoiesis? // Exp. Hematol. - 2003. - Vol. 21. - P. 823-842.

Dadachova E, Ruth A. Bryan R.A, Howell R.C., Schweitzer A.D., Aisen P., Nosanchuk J.D., Arturo Casadevall A.C. The radioprotective properties of fungal melanin are a function of its chemical composition, stable radical presence and spatial arrangement. Pigment Cell \& Melanoma Research. Vol. 21, Issue 2, April 2008. P. 192-199.

Danchenko M, Skultety L, Rashydov N.M., Berezhna V.V, Mátel L, Salaj T, Pret'ová A, Hajduch M. Proteomic analysis of mature soybean seeds from the Chernobyl area suggests plant adaptation to the contaminated environment// J. Proteome Res. 2009, 8: 2915-2922.

Danchenko, M., Škultéty, L., Berezhna, V.V., Rashydov, N.M. , Pret’ová, A. , Hajduch, M. Twenty one years since Chernobyl disaster; What seed protein can tell us? Cordova, Spain, 2008, p.134

Danchenko M, Klubicova K, Skultety L, Berezhna V, Rashydov N, Hajduch M. Concept of crop adaptation to the Chernobyl environment based on proteomic data//Climate Change: Challenges and Opportunities in Agriculture, Budapest, Hungary, 2123/03/ 2011, p. 151-154.

Down J., Van Os. R., Ploemacher R. Radiation sensitivity and repair of long-term repopulating bone marrow stem cells. // Exp. Hematol. - 1991. - Vol. 19. - P. 474 $-486$.

Elmendorff-Dreikorn K., Chauvin C, Slor H., Joachim Kutzner, Werner Muller E.G. Assessment of DNA damage and repair in human peripheral blood mononuclear cells using a novel DNA unwinding technique // Cellular and Molecular Biology. 1999. Vol.45 (2), P. 211-218.

Ermakov A.V., Kon'kova M.S., Kostyuk S.V., Ershov E.S., Egolina N.A., Veiko N.N. Fragments of DNA from the extracellular medium of incubation of human lymphocytes irradiated at low doses, trigger the development of oxidative stress and adaptive response in unexposed bystander lymphocytes / / Radiats. Biol. Radioekol. 2009. T. 48, № 5. P. 553-564. 
Fernet M, Megnin-Chanet F, Hall J, Favaudon V. Control of the G2/M checkpoints after exposure to low doses of ionising radiation: implications for hyperradiosensitivity// DNA Repair (Amst). 2010, 9(1) p.48-57.

Friedburg E.C., Walker G.C., Siede W, Wool R.D, Schult R.A., Ellenverger T. DNA repair and mutagenesis. Washington, DC.: ASM Press. 2006. 1118 p.

Gaziyev A.I. Low efficiency of repair of critical DNA damage caused by low doses of radiation. 2011 (in press).

Goldberg E.D., Dygai A.M. Dynamic theory of regulation of hematopoiesis and the role of cytokines in the regulation of gemopoeza / / Medical Immunology. - 2001. Volume 3, № 4. P. 487-497.

Grande T., Varas F., Bueren J.A. Residual damage of lymphohematopoietic repopulating cells after irradiation of mice at different stages of development. // Exp. Hematol . - 2000. - Vol. 28. - P. 87.

Grosovsky A.J. Radiation-induced mutations in unirradiated DNA // Proc. Natl. Acad. Sci. 1999. V.96. N.10. P.46-53.

Grudzenskia S., Rathsa A., Conrada S., C.E. Rubeb, M. Lobrich, Inducible response required for repair of low-dose radiation damage in human fibroblasts. PNAS, 2010, 107, 32,14205-14210.

Gusev M.V., Mineeva L.A. Microbiology. 3rd ed. M: publ. MGU, 1992.-448 p.

Hada M., Georgakilas A.C. Formation of clustered DNA damage after high-LET irradiation: a rewiev// J. Radiat. Res. 2008. V.49. P.203-210.

Hall E.J. Radiology for the Radiologist. Philadelphia: LippincottCo. - 1991. - 334 p.;

Hall Mauch P., Constine L., Greenberger J., Knospe W., Sullivan J., Liesveld J.L., Deeg H.J. Hematopoietic stem cell compartment: acute and late effects of radiation therapy and chemotherapy. / / Int J Radiat Oncol Biol Phys. - 2005. -Vol. 3. - P.1319-39.

Harel M., Shoenfeld Y. Predicting and preventing Autoimmunity, myth or reality// Ann. N.Y. Acad. Sci. 2006. 1069: 322-346.

Hildebrandt G. Non-cancer diseases and non-targeted effects. //Mutat. Res. 1996, 687; 7377.

Hopkins W.G., Huner N.P.A. Introduction to Plant Physiology. 2009, Wiley, USA, 503 p.

Howell C.R., Schweitzer A.D., Casadevall A., Dadachova E. A. Chemosorption of radiometals of interest to nuclear medicine by synthetic melanins. Nucl Med Biol. 2008 April; 35(3): 353-357.

Ide H., Shoulkamy M.I., Nakano T., Miyamoto-Matsubara M, Salem AM. Repair and biochemical effects of DNA-protein crosslink. // Mutat. Res. 2010, V704, P.172183.

Johansen C.O. Cellular telephones, magnetic field exposure, risk of brain tumors and cancer at other sites in cohort study //Radiat. Brot. DOSIM. 1999. V.83. N.1-2. P. 155-157.

Kovalev V., Krul N., Zhezhera V., Seniuk O. Autoimmune hepatitis as a result of chronic exposure to low doses of radiation. /Uzhgorod University Scientific Bulletin Series of Biology Issue 27. 2010: P.245-249.

Kovalev V.A., Senyuk O.F. The state of tolerance under the influence of ionizing radiation "Chernobyl of the spectrum" /Ecological Bulletin, Minsk. 2008. № 2 (5). p. 36-42. 
Kudryashov Yu.B. Radiation Biophysics (Ionizing radiation). Ed. By Mazurik V.K., Lomanova M.F. 2004. 448. www.medliter.com. (in Russian).

Kutsokon N., Lazarenko L.M., Bezrukov V.F., Rashydov N.M., Grodzinsky D. The number of aberrations per cell is an index of chromosome instability. 2. Comparative analysis of effects produced by factors of various natures. Cytology and Genetics 2004, Jan-Feb; 38(1), p. 49-57.

Kutsokon N., Rashydov N.M., Berezhna V., Grodzinsky D. Biotesting of radiation pollutions genotoxicity with the plants bioassays. Radiation safety problems in the Caspian region. Kluwer Academic Publishers. 2004. P. 51 - 56

Kutsokon N., Rashydov N.M., Grodzinsky D., Bezrukov V.F., Lazarenko L.M. Number of aberrations in an abnormal cells as a parameter of chromosomal instability. 1. Characteristics of dosage dependences. Cytology and Genetics 2003, Jul-Aug; 37(4), p. 17-24.

Kutsokon N.K., Rashydov N.M., Grodzinsky D.M. Cytogenetic effects of ${ }^{241}$ Am in Alliumtest. In Book "Int. Conf. "Genetic Consequences of Emergency Radiation Situations", Moscow, 2002. - P.146 - 148.

Lindahl T. Instability and decay of the primary structure of DNA. // Nature. 1993. V362. P. $709-715$.

Little D.B. Not target effects of ionizing radiation: findings in relation to low-dose effects. / / Radiation Biology. Radioecology. 2007, V.47, N 3, p. 262-272.

Little J.B. Radiation carcinogenesis. // Carcinomogenesis, 2000. V.21. N3. P.397-400.; Little J.B. Genomic instability and bystander effects: A historical perspective. // Oncogene. 2003. V.22. P.6978-6987.

Lorimore S.A., Coates P.J., Scobie G.E., Milne G., Wright E.G. 1nflammatory-type responses after exposure to ionizing radiation in vivo: a mechanism for radiation induced bystander effects? Oncogene. 2001. N.20. P.708-595.

Maltsev V.N. Quantitative regularities of radiation immunology. -M.: 1983. ???? p.

Manns M, Gerken G, Kyriatsoulis A, Staritz M, Meyer zum Büschenfelde K-H. Characterisation of a new subgroup of autuimmune chronic active hepatitis by autoantibodies against a soluble liver antigen / / Lancet. - 1987. - P. 292 - 294.

Marples B., Wouters B.G., Collis S.J., Chalmers AJ, Joiner MC. Low-dose hyperradiosensitivity: a consequence of ineffective cell cycle arrest of radiation-damaged G2-phase cells. Radiat Res 161:247-255; 2004.

McFarlane I.G., Wojicicka B.M., Zucker G.M., Eddleston AL, Williams R. Purification and Characterization of human liver-specific membrane lipoprotein (LSP) / / Clin. Exp. Immunol. - 1977. - 27, № 3. - P. 381-390.

Mosse I.B. Modern Problems biodosimetry// Radiation Biology. Radioecology. 2002., 42 . № 6. pp. 661-664 (in Russian).

Mosse I.B., Dubovic B.V., Plotnikova S.I., Kostrova L.N., Subbot S.T. Melanin decreases remote consequences of long-term irradiation. // Proc.f 9th Int. Congr. on Radiation Protection. Vienna, Austria, 14-19 April 1996. - Vienna, 1996. - V. 2. - P. 127-129.

Mosse I.B., Lyach I.P. Influence of melanin on mutation load in Drosophila population after long-term irradiation. // Radiation Research. - 1994. - V.139. - №3. - P.356-358. 
Mosse I.B., Zhavoronkov L.P., Molofey V.P., Izmestieva O.S., Posad V.M., Izmest'ev V.I. Development on the basis melanin means of prevention of genetic and ontogenetic effects of irradiation. Vestnik VOGiS, 2005, Vol. 9, № 4, p. 527-533.

Mothersill C., Seymour C.B. Cell-cell contact during gamma irradiation is not required to induce a bystander effect in normal human keratinocytes: evidence for release during irradiation of a signal controlling survival into the medium// Radiat. Res. 1998. V.149. P. 256-262.

Mothersill, C. Seymour, C. Radiation-induced bystander effects: past history and future direction. Radiat. Res. 2001. V. 155, P. 759-767.

Muksinova K.N., Mushkacheva G.S. Cellular and molecular basis of the restructuring of hematopoiesis in long-term radiation exposure. Moscow: Energoatomizdat, 1995. $161 \mathrm{p}$.

Nagasawa H, Little J.B. Induction of sister chromatid exchanges by extremely low doses of a-particles. Cancer Res 1992;V.52. P.6394-6396.

Narayanan P.K., Googwin E.Y, Lehnert B.E. Alpha particles initiate biological production of superoxide anions and hydrogen peroxide in human cells / / Cancer Res. 1997. Vol. 57. N 18. P.3963-3971.

NCR (National Research Council of the National Academies). / Health Risk from Exposure to Low Level of Ionizing Radiation (BEIR VII, Phase II). National Academies Press, Washington, DC, 2006. P. 386.

Nobler M.P. The abscopal effect in malignant lymphoma and its relationship to lymphocyte circulation. Radiobiology. 1969. V.93. P. 410-412.

Notkins A.L. New predictors of disease / / Scientific American 2007, V. 296. No 3. P.72-80.

Oxidative Stress: Oxidants and Antioxidants /Ed. Sies H. N.Y.: Academic, 1991. 546 p.

Pazuhin E.M., Krasnov V.A., Lagunenko A.S., B.I. Ogorodnikov, N.I.Pavljuchenko, V.E. Khan, A.A.Odintsov, V.B.Rybalka, G.I.Petelin, Yu.I.Zimin, I.N. Kantseva. Studying of physical and chemical properties of nuclear danger divising materials influencing a degree of nuclear, radiating and ecological safety of object "Shelter". // Problems of Chornobyl. Issue 14. 2004. p. 129 - 136.

Petelin G.I., Zimin Yu.I., Tepikin V.E., V.B. Rybalka, E.M. Pazuhin. "Hot" particles of nuclear fuel of Chernobyl emission in a retrospective estimation of emergency processes on 4-th block ChNPP. Radiochemistry, 2003, V.45, No 3, PP 278-281;

Pfeiffer P., Gottlich B., Reichenberger S., Feldmann, E.; Daza, P.; Ward, J. F.; Milligan, J. R.; Mullenders, L. H. F.; Natarajan, A. T., DNA Lesions and Repair. Mut. Res. Rev. Gen. Tox. 1996, 366 (2) 69-80.

Poletayev A.B. About the "difficult issues" of autoimmunity, or as the concept of immunkuluma can become the foundation of preventive medicine. // Medicine XX I. 2008. № 2 (11). P.84-91. Cohen I.R. The Immunological gomunculus spears in microarray. Natural autoimmunity in physiology and pathology abstracts. 2005. P.13.

Poletayev A.B. Immunophysiology and immunopathology. - Moscow: MIA, 2008. 208 p.

Preston D.L, Shimuzu Y, Pierce DA, Suyama A and Mabuchhi K. Studies of mortality of Atomic Bomb survivors. (2003) Report 13: Solid Cancer and Non-cancer Disease Mortality: 1950-1997 Radiation Research Vol. 160: P. 381-407 
Radulescu I., Elmroth K., Stenerlow B. Chromatin organization contributes to non-randomy distributed / / Radiat. Res. 2004. V.161. P.1 -8.

Rashydov N., Berezhna V. Distribution ${ }^{241} \mathrm{Am}$ by organs and tissues of plants. In: Nuclear Track Detectors: Design, Methods and Applications ISBN: $\quad$ 978-1-60876-826-4 (Editor: Maksim Sidorov and Oleg Ivanov), Nova Science Publishers, Inc., USA, chapter 7, 2010, p. 213-225.

Rashydov N., Berezhna V., Kutsokon N. Evaluation of water and soil genotoxicity with bioassays in sites contaminated with radionuclides. Proceedings "Sustainable Water Management" MEDA Water International Conference, Tunis, 2007 p. 307313.

Rashydov N.M. Characterization risk of the contamination water pathways and determination of toxicity. Abstract book NATO Advanced research workshop on "Climate change and its effect on water resources - Issues of national and global security" Editors: Alper Baba. Goknem Tayfur, Irem Shahin (Izmir, Turkey 01-04 September 2010) p. 26.

Rashydov N.M. Risk characterization of the contamination water pathways and determination of toxicity. In book issues NATO Advanced research workshop on "Climate change and its effect on water resources - Issues of national and global security". Chapter 18, Editors: Alper B. Goknem T. \& Orhan G. Springer, 2011, p. 157-165.

Rashydov N.M. Study radiosensitivity seeds Oenothera biennis L. grown in conditions chronic irradiation// In book: Study ontogenesis of plants natural and cultural flora in botanical organizations and in arboretum of Europe - Asia, Bila Tserkva, 1999, p.237-240.

Rashydov N.M., Berezhna V.V., Grodzinsky D.M. Radiobiological effects of ${ }^{241} \mathrm{Am}$ incorporated in cells of organism and methods of prevention of the menace of combined toxicity of the transuranic elements // In book: Aycik, Gul Asiye. New techniques for the detection of nuclear and radioactive agents. Springer, Verlag, 2009. - 347, p.313-323.

Rashydov N.M., Grodzinsky D., Berezhna V., Sakada V. The study of adaptation responses under $\gamma$-irradiation of transgenic lines Arabidopsis thaliana L. Proceedings of the 35th Annual Meeting of the European Radiation Research Society. Current problems of radiation research, Kyiv, Ukraine (Edited by D. Grodzinsky \& A. Dmitriev) 2006, p. 227-235.

Rashydov N.M., Konoplyova A.A., Grodzinsky D.M. Research of possible mechanisms of morphogenetic processes suppression in tissue culture, donor plants of which were exposed under action of chronic irradiation. Scientific papers of the Institute for Nuclear Research, Kiev, Ukraine. 2004, N 2 (13), p. 122-132.

Rashydov N.M., Kutsokon N.K. Target and non-target radiobiological reactions - its threshold and non-threshold effects. Problems of nuclear power plants safety and of Chernobyl. V3, N2, 2005. p. 42-49.

Rashydov N.M., Kutsokon N.K. Effects of chronic irradiation of plants deal with radionuclides man-caused origin. D. M. Grodzinsky (Editor), Radiobiological 
effects chronic irradiation of plants in zone influence Chernobyl catastrophe. P.70134, 373p. (2008) (in Ukrainian).

Riley P.A. Melanin // Int. J. Biochem. Cell. Biol. 1997. Vol. 29. No. 11. P.1235-1239.

Ryabenko D.V., Sidorik L.L., Sergienko O.V., Trunina I.V., Bobyk V.I., Fedorkova O,M., Kovenia T.V., Matsuka G.Kh. Myosin-induced myocardial damage: experimental study// Ukrainian Rheumatology Journal - 2001. - 3, №1. - P. 58-61.

Rybalka V., Klechkovskaja E., Serbinovich V., Petelin G., Kantzeva I. The microbiological factor and possibilities of radionuclides outwash control, changing of its uptake by plants on an example of the contaminated soils of Chernobyl zone. International Conference, Prague, 11-13 September 2001 Crop Science on the verge of the 21-th Century - Opportunities and Challenges/Proceedings, P.164-167.

Rybalka V.B., G.F. Smirnova, G.I.Petelin, I.N.Kantseva, V.V. Serbinovich, V.A. Krasnov, V.E. Khan. The microbic factor, fuel containing materials and formation of submicronic particles in object "Shelter". Problems of safety of nuclear power Plants and of Chornobyl. Issue.3. P.1. 2005. P. 87-97.

Rybalka V.B., Rybalko S.I., Zimin Yu.I., Petelin G.I., Rybakova E.A., Tepikin V.E. "Hot" particles of the Chernobyl exclusion zone in the esearch by electron microscopy. Atlas. ISBN 966-7654-41-9. Chornobyl Center radioecological, Chernobyl, 2001, $52 \mathrm{p}$.

Schweitzer A. D., Robertha C. Howell R.C., Jiang Z., Ruth A. Bryan R.A., Gerfen G., Chen Ch.Ch., Mah D., Cahill S., Casadevall A, Dadachova E. Physico-Chemical Evaluation of Rationally Designed Melanins as Novel Nature-Inspired Radioprotectors. PLoS One. 2009; 4(9): p. 7229.

Senyuk O., Gorovoj L., Zhidkov A., V. Kovalev, L. Palamar, V. Kurchenko, N. Kurchenko, $\mathrm{H}-\mathrm{Ch}$. Schroeder. Genome protection properties of the chitin-containing preparation Mycoton In: Advances in chitin science Vol. VIII. Print. by ESUS, Poznan. 2005. P.430-439.

Serkiz Ya.I., Pinchuk L.B. Radiobiological effects of the accident at Chernobyl nuclear power plant. - K.: Naukova Dumka. -1992. - 172 p.

Seymour C.B., Mothersill C. Delayed expression of lethal mutations and genomic instability in the progeny of human epithelial cells that survived in a bystander-killing environment / / Radiat. Oncol. Investig. 1997. V. 5. No3. P.106-110.

Seymour C.B., Mothersill C., Alper T. High yields of lethal mutations in somatic mammalian cells that survive ionizing radiation. // Int. J. Radiat. Biol. Relat. Stud. Phys.Chem. Med. 1986. V.50. N1. P. 167-179.

Shikazono N., Noguchi M., Fujii K., Urushibara A., Yokoya A. The Yield, processing and biological consequences of clustered DNA damage induced by ionizing radiation // J.Radiat.Res. 2009. V.50. p.27-36.

Shoenfeld Y. The Mosaic of Autoimmunity Predicting and treatment in autoimmune disease. IMAJ: 2008. Vol.10. P.12-19.

Shouse S.S., Warren A.S.L., Whipple G.H. Apalasia of marrow and fatal intoxication in dogs produced by roentgen irradiation of all bones. // Exp. Med. - 2004. - Vol. 53. - P. 42 -98 . 
Sidorik E.P., Druzhina M.O., Burlaka A..P, Danko M.Y., Pukhov F . G. Zhdanova, N.N, Shkolniy O.T. (1994) Dokl. Ukrainian Academy of Sciences. № 9, 174-178 (in Ukrainian).

Sinitsky V.N., Kovtun T.V., Kharchenko, N.K. et al. Pathological mechanisms of maladaptation of the central nervous system in humans exposed to radiation // Fiziol. Journ. - 1995. - T. 41, № 3 - 4. - p. 55 - 66.

Snyder A.R. Review of radiation-induced bystander effects. Human \& Experimental Toxicology. 2004. N. 23, P. 87 - 89, www.hetjournal.com.

Storer J.B. Acute responses to ionizing radiation//in: Biology of the laboratory mouse., Ed. E.L.Green., N.Y. 1966. P.427-446.

Sutherland B.M., Bennet P.V., Sidorkina O., Laval L. Clustered DNA induced by isolated DNA and in Human Cells by Low Doses of ionizing Radiation / / Proc. Natl. Acad. Sci. USA. 2000. V.97, P.103-108.

Tabachnikov S.I., Shtengelov V.V., Danilov V.M., O.F.Seniuk, V.N. Oskina. Characteristics of brain bioelectric activity, psychological and emotional sphere, the cytokine network and biogenic amines in conditions of prolonged exposure of the complex factors the "Shelter" / Problems of Chornobyl. Issuence 10, Part.II., Chornobyl 2002 .- PP. $252-261$.

Tavassoli M.V. Bone marrow: the seedbed of blood. In: Wintrobe MM, ed. Blood, pure and eloquent: a story of discovery, of people, and of ideas. / / New York: McGraw-Hill. - 2008. - P. 57-79.

Timofeev-Resovskii N.V. The primary mechanisms of biological action of ionizing radiation. - M.: AScUSSR - 1963. P. 162-164.

Tsyb A.F., Budagov R.S., Zamulaeva A.I. Radiation and pathology. - M.: Vysshaya. shkola. 2005. - 314 p. (in Russian).

Von Sonntag C. / Free-Radical-induced DNA Damage and its Repair. Heidelberg. Springer. Verlag. 2006. P465.

Walker C. Radiation enhanced diffusion and gas release from recrystallized $\mathrm{UO}_{2}$ grains in high burn-up water reactor fuel. //Annual report of Institute for Transuranium elements, Karlsruhe, JRC, EC, 2000, Report EUR 19812 BN, sect. 3.1.4, p.86-87.

Ward J.F. DNA damage produced by ionizing radiation in mammalian cells: identities, mechanisms of formation and reparability.// Prog. Nucleic Acid Res. Mol. Biol. 1988. V.35 P.95-125.

Watson G.E., Lorimore S.A., Macdonald D.A., Wright EG. Chromosomal instability in unirradiated cells induced in vivo by a bystander effect of ionizing radiation. Cancer Res 2000. Oct.15.V.60. N, 20.P. 5608 - 5611.

Zaichik A. Sh, Churilov LP Fundamentals of general embryology. St. Petersburg: ELBI-St. 1988. 440 p.

Zaichik A. Sh., Churilov L.P. Total pathophysiology with the basics of immunopathology. Ed. 4-e. St. Petersburg: 2008b. ELBI-St. p.490-491.

Zaichik A.Sh., Churilov L.P. Natural autoimmunity as a synchronization system of genetically determined processes. Immunophysiology. Natural autoimmunity in health and disease. Moscow. 2008a. P.73-91. 
Zhdanova N.N., Zakharchenko V.A., Tugay T.I., Yu.V. Karpenko, L.T. Nakonechnaya, A.K. Pavlichenko, V.A. Zheltonozhsky, A.V. Zhydkov, O.F. Seniuk. Fungal damage of "Shelter" // Problems of safety of nuclear power Plants and of Chornobyl. Issue.3. P.1. 2005. P. 78-86.

Zedman, A.J.W., Vossenaar E.R. Autoantibodies to circulated (poly) peptides: a key diagnostic and prognostic marker for rheumathoid arthritis. Autoimmunity. 2004. 37. P. 295-299. 


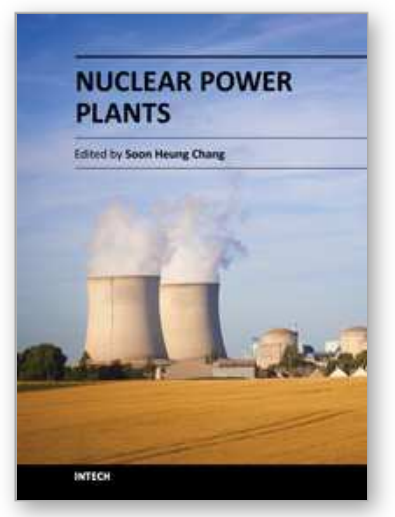

\author{
Nuclear Power Plants \\ Edited by Dr. Soon Heung Chang
}

ISBN 978-953-51-0408-7

Hard cover, 340 pages

Publisher InTech

Published online 21, March, 2012

Published in print edition March, 2012

This book covers various topics, from thermal-hydraulic analysis to the safety analysis of nuclear power plant. It does not focus only on current power plant issues. Instead, it aims to address the challenging ideas that can be implemented in and used for the development of future nuclear power plants. This book will take the readers into the world of innovative research and development of future plants. Find your interests inside this book!

\title{
How to reference
}

In order to correctly reference this scholarly work, feel free to copy and paste the following:

Rashydov Namik, Kliuchnikov Olexander, Seniuk Olga, Gorovyy Leontiy, Zhidkov Alexander, Ribalka Valeriy, Berezhna Valentyna, Bilko Nadiya, Sakada Volodimir, Bilko Denis, Borbuliak Irina, Kovalev Vasiliy, Krul Mikola, Petelin Grigoriy (2012). Radiobiological Characterization Environment Around Object "Shelter", Nuclear Power Plants, Dr. Soon Heung Chang (Ed.), ISBN: 978-953-51-0408-7, InTech, Available from:

http://www.intechopen.com/books/nuclear-power-plants/radiobiologic-characterization-environment-aroundobject-shelter-

\section{INTECH}

open science | open minds

\section{InTech Europe}

University Campus STeP Ri Slavka Krautzeka 83/A 51000 Rijeka, Croatia Phone: +385 (51) 770447

Fax: +385 (51) 686166 www.intechopen.com

\section{InTech China}

Unit 405, Office Block, Hotel Equatorial Shanghai No.65, Yan An Road (West), Shanghai, 200040, China 中国上海市延安西路65号上海国际贵都大饭店办公楼 405 单元 Phone: +86-21-62489820

Fax: $+86-21-62489821$ 
(C) 2012 The Author(s). Licensee IntechOpen. This is an open access article distributed under the terms of the Creative Commons Attribution 3.0 License, which permits unrestricted use, distribution, and reproduction in any medium, provided the original work is properly cited. 